medRxiv preprint doi: https://doi.org/10.1101/2021.08.03.21260940; this version posted August 5, 2021. The copyright holder for this preprint (which was not certified by peer review) is the author/funder, who has granted medRxiv a license to display the preprint in perpetuity.

It is made available under a CC-BY 4.0 International license.

\title{
Symptom Persistence Despite Improvement in Cardiopulmonary Health - Insights from longitudinal CMR, CPET and lung function testing post-COVID-19
}

Brief Title: Longitudinal study of cardiopulmonary health in COVID-19

Mark Philip Cassar, MD (Melit.) ${ }^{\mathrm{a}, \mathrm{b}}$, Elizabeth M. Tunnicliffe, $\mathrm{PhD}^{\mathrm{a}}$, Nayia Petousi, DPhil ${ }^{\mathrm{c}, \mathrm{d}}$, Adam J. Lewandowski, DPhil ${ }^{\mathrm{a}}$, Cheng Xie, FRCR ${ }^{\mathrm{e}, \mathrm{f}}$, Masliza Mahmod, DPhil ${ }^{\mathrm{a}, \mathrm{b}}$, Azlan Helmy Abd Samat, DrEmMed ${ }^{\mathrm{a}, \mathrm{b}}$, Rachael A. Evans, PhD $^{\mathrm{g}, \mathrm{h}}$, Christopher E. Brightling, MD ${ }^{\mathrm{g}, \mathrm{h}}$, Ling-Pei Ho, DPhil $^{\mathrm{d}, \mathrm{i}}$, Stefan K. Piechnik, DSc ${ }^{\mathrm{a}}$, Nick P. Talbot, DPhil ${ }^{\mathrm{d}, \mathrm{j}}$, David Holdsworth, DPhil $^{\text {d,j }}$, Vanessa M. Ferreira, DPhil ${ }^{\mathrm{a}, \mathrm{b}}$, Stefan Neubauer, MD ${ }^{\mathrm{a}, \mathrm{b}, \mathrm{e}}$, and Betty Raman, DPhil ${ }^{\mathrm{a}, \mathrm{b}, \mathrm{e}}$

\section{Affiliations}

a. Division of Cardiovascular Medicine, Radcliffe Department of Medicine, National Institute for Health Research (NIHR) Oxford Biomedical Research Centre (BRC), University of Oxford, Oxford, United Kingdom

b. Department of Cardiology, Oxford University Hospitals NHS Foundation Trust, Oxford, United Kingdom

c. Nuffield Department of Medicine, University of Oxford, Oxford, United Kingdom

d. Department of Respiratory Medicine, Oxford University Hospitals NHS Foundation Trust, Oxford, United Kingdom

e. Radcliffe Department of Medicine, British Heart Foundation Centre for Research Excellence, University of Oxford, Oxford, United Kingdom

f. Department of Radiology, Oxford University Hospitals NHS Foundation Trust, Oxford, United Kingdom

g. NIHR Biomedical Research Centre (Respiratory theme), University Hospitals of Leicester NHS Trust, Leicester, UK

h. Department of Respiratory Science, University of Leicester, Leicester, UK

i. Weatherall Institute of Molecular Medicine, Nuffield Department of Medicine, University of Oxford, Oxford, United Kingdom

j. Department of Physiology, Anatomy and Genetics, University of Oxford, Oxford, United Kingdom

\section{Corresponding Author}

Dr Betty Raman

Oxford Centre for Clinical Magnetic Resonance Research

Level 0, John Radcliffe Hospital

Headington, Oxford, OX3 9DU

United Kingdom

Email address: Betty.raman@cardiov.ox.ac.uk

Telephone number: 00441865234580 


\section{Abstract \\ Background}

The longitudinal trajectories of cardiopulmonary abnormalities and symptoms following infection with coronavirus disease (COVID-19) are unclear. We sought to describe their natural history in previously hospitalised patients, compare this with controls, and assess the relationship between symptoms and cardiopulmonary impairment at 6 months post-COVID19.

\section{Methods}

Fifty-eight patients and thirty matched controls underwent symptom-questionnaires, cardiac and lung magnetic resonance imaging (CMR), cardiopulmonary exercise test (CPET), and spirometry at 3 months following COVID-19. Of them, forty-six patients returned for followup assessments at 6 months.

\section{Findings}

At 2-3 months, $83 \%$ of patients had at least one cardiopulmonary symptom versus $33 \%$ of controls. Patients and controls had comparable biventricular volumes and function. Native cardiac $\mathrm{T}_{1}$ (marker of inflammation) and late gadolinium enhancement (LGE, marker of focal fibrosis) were increased in patients. Sixty percent of patients had lung parenchymal abnormalities on CMR and 55\% had reduced peak oxygen consumption $\left(\mathrm{pVO}_{2}\right)$ on CPET.

By 6 months, 53\% of patients remained symptomatic. On CMR, indexed right ventricular (RV) end-diastolic volume $\left(-4.3 \mathrm{mls} / \mathrm{m}^{2}, P=0.005\right)$ decreased and $\mathrm{RV}$ ejection fraction $(+3 \cdot 2 \%, P=0.0003)$ increased. Native $\mathrm{T}_{1}$ and LGE improved and was comparable to controls. Lung parenchymal abnormalities and peak $\mathrm{VO}_{2}$, although better, were abnormal in patients versus controls. $31 \%$ had reduced $\mathrm{pVO}_{2}$ secondary to fatigue and submaximal tests. 
Cardiopulmonary symptoms in patients did not associate with CMR, lung function, or CPET measures.

\section{Interpretation}

In patients, cardiopulmonary abnormalities improve over time, though some measures remain abnormal relative to controls. Persistent symptoms at 6 months post-COVID-19 did not associate with objective measures of cardiopulmonary health.

\section{Funding}

NIHR Oxford and Oxford Health BRC, Oxford BHF CRE, UKRI and Wellcome Trust. 
medRxiv preprint doi: https://doi.org/10.1101/2021.08.03.21260940; this version posted August 5, 2021. The copyright holder for this preprint (which was not certified by peer review) is the author/funder, who has granted medRxiv a license to display the preprint in perpetuity.

It is made available under a CC-BY 4.0 International license .

\section{Introduction}

First described in December $2019,{ }^{1}$ severe acute respiratory syndrome coronavirus-2 (SARSCoV-2), a beta coronavirus, is responsible for coronavirus disease (COVID-19). Our understanding of how this virus came to invade human cell lines has rapidly evolved, as the role of Angiotensin-converting enzyme-2 receptors in facilitating viral entry into cells was elucidated. ${ }^{2}$ Angiotensin-converting enzyme-2 receptors are not only present in type II pneumocytes but are ubiquitously expressed by the vascular cells and other visceral organs. ${ }^{3}$ The effect of SARS-CoV-2 on the heart is of particular importance, as it can cause a range of abnormalities including myocardial dysfunction, inflammation, and ischemic damage via direct (cytotoxic) and indirect (dysregulated immune response, thrombo-inflammation) mechanisms. ${ }^{4}$ Myocardial injury is more common in moderate to severe infections and predictive of poor clinical outcomes among those admitted to hospital. ${ }^{5}$ A number of recent studies have highlighted the role of cardiac magnetic resonance imaging (CMR) and cardiopulmonary exercise testing (CPET) in evaluating the mechanisms and functional consequences of cardiopulmonary injury in COVID-19 survivors. $^{5-7}$ Detailed assessments have typically been undertaken at a single time point within weeks to months after infection and do not reveal the natural history of cardiopulmonary pathology. A high burden of cardiopulmonary symptoms has also been reported and the role of contemporaneous investigations in elucidating the underlying cause for symptoms is unknown.

Previously, we undertook a holistic assessment of COVID-19 patients at 2-3 months following moderate to severe infection using symptom-based questionnaires, multiorgan magnetic resonance imaging (MRI), spirometry, and CPET. ${ }^{8}$ We observed a high prevalence of tissue abnormalities involving the heart (26\%) and lungs $(60 \%)$ on MRI, together with reduced forced expiratory volume in 1 second $\left(\mathrm{FEV}_{1}\right)$ and forced vital capacity $(\mathrm{FVC})$ and marked exercise intolerance on CPET in patients. Here, we sought to describe the time course 
evolution of cardiopulmonary symptoms, CMR, pulmonary function and CPET abnormalities in these patients from 2-3 months to 6 months and evaluate the relationship between symptoms and objective measures of cardiopulmonary health at 6 months.

This study was registered at ClinicalTrials.gov (NCT04510025) and approved in the United Kingdom by the North West Preston Research Ethics Committee (reference 20/NW/0235).

\section{Methods}

\section{Study population}

Fifty-eight patients with moderate to severe laboratory-confirmed (SARS-CoV-2 polymerase chain reaction positive) COVID-19, admitted for inpatient treatment at the Oxford University Hospitals National Health Service Foundation Trust, and 30 SARS-CoV-2 immunoglobulin negative controls, group-matched for age, sex, body mass index and risk factors (smoking, diabetes, and hypertension) from the community (recruited during the same period) were prospectively enrolled in this observational cohort study as previously described. A flow chart for recruitment is listed in the Supplementary Material, p7.

\section{Study procedures}

Informed consent was obtained from all patients. Patient health questionnaires, cardiopulmonary magnetic resonance imaging, spirometry, CPET, electrocardiogram (ECG) and blood tests were undertaken in patients at 2-3 months and 6 months post-infection and at a single time point in controls. Gas transfer assessments were undertaken in patients at 6 months alone.

Disease severity was graded using the World Health Organisation ordinal scale for clinical improvement. ${ }^{9}$ Patients with severe illness were defined as those having a score of $\geq 5$ (high flow oxygen, non-invasive and invasive ventilation). 
An electrocardiogram (ECG) was performed for every participant and interpreted according to the Minnesota Code of Electrocardiographic Findings. ${ }^{10}$

Patient health questionnaire-15 (PHQ-15) ${ }^{11}$ was completed using an electronic data capture platform (CASTOR EDC, https://www.castoredc.com). The Medical Research Council (MRC) dyspnoea scale ${ }^{12}$ and Fatigue Severity Scale (FSS) ${ }^{13}$ were used to assess the prevalence and severity of breathlessness and fatigue, respectively (Supplementary material, p3).

CMR was carried out at 3 Tesla (Prisma, Siemens Healthineers, Erlangen, Germany) and included cine imaging to assess biventricular volumes, $T_{1}$ and $T_{2}$ mapping to assess myocardial inflammation and oedema, and post-contrast $\mathrm{T}_{1}$ mapping and late gadolinium enhancement (LGE) imaging to assess diffuse and focal/patchy fibrosis. Lung abnormalities were assessed using Half-Fourier-acquisition single $\square$ shot turbo spin $\square$ echo (HASTE) MRI before the administration of contrast (Supplementary Material, p3).

CMR studies were analysed using CVI42 5.11.4 (Circle Cardiovascular Imaging, Calgary, Canada). All cardiac images were analysed by CMR experts (BR, MC) (Supplementary Material, p4). Lung images were qualitatively assessed for parenchymal involvement by an expert radiologist $(\mathrm{CX})$, with the extent of lung parenchymal opacities scored as $0(0 \%), 1$ (1$25 \%), 2(26-50 \%), 3(51-75 \%)$, or $4(76-100 \%) .{ }^{14}$

Spirometry, including FVC and $\mathrm{FEV}_{1}$, was performed as per recommended guidance. ${ }^{15}$ Diffusion capacity for carbon monoxide $\left(\mathrm{DL}_{\mathrm{CO}}\right)$ and alveolar volume $(\mathrm{Va})$ were measured using a ten-second single breath-hold technique with methane as the tracer gas, and adjusted for hemoglobin. ${ }^{16}$ 
Symptom-limited incremental CPET was undertaken using a cycle ergometer as previously described. Following two minutes of unloaded cycling, the work rate was increased to $20 \mathrm{~W}$, followed by a 10W/min ramp (Supplementary Material, p5). ${ }^{17}$

Blood-based testing consisted of complete blood count, biochemical analysis, coagulation testing, liver and renal function assessment, markers of cardiac injury (troponin $\mathrm{T}$ and $\mathrm{N}$ terminal pro-brain natriuretic peptide/NT-proBNP), and measures of electrolytes, C-reactive protein $(\mathrm{CRP})$, and procalcitonin.

Details on clinical symptoms, signs, vitals, and laboratory findings during admission were extracted from electronic medical records. ${ }^{18}$

\section{Statistics}

Continuous variables were described using mean and standard deviation for variables with parametric data across all groups. When non-parametric data was present in one or more groups, median and interquartile range (IQR) was used to facilitate comparison. Normality was assessed by the Shapiro-Wilk test. Group differences were evaluated using Student's ttests, Mann-Whitney U-tests, paired Student's t-tests, and Wilcoxon Signed Ranks tests as appropriate. Categorical variables were reported as frequency and percentages, with group differences evaluated using the Chi-square test, Fisher's exact test, Fisher-Freeman-Halton exact test, Stuart-Maxwell test, or McNemar test as appropriate. Spearman's correlation coefficients were used to describe the relationship between two variables where relevant. Univariate binary logistic regression was used to determine the association of cardiopulmonary symptoms (chest pain, palpitations, syncope, dyspnoea, or dizziness) and objective measures of cardiopulmonary health. For any univariate association with a $P$-value of $<0.05$, we planned to undertake a multivariable logistic regression. 
medRxiv preprint doi: https://doi.org/10.1101/2021.08.03.21260940; this version posted August 5, 2021. The copyright holder for this preprint (which was not certified by peer review) is the author/funder, who has granted medRxiv a license to display the preprint in perpetuity.

It is made available under a CC-BY 4.0 International license .

In a separate analysis, determinants of breathlessness were also ascertained (Supplementary Material, p8). The conventional level of statistical significance of 5\% was used. Statistical analyses were performed using SPSS Version 27.0 (IBM, Armonk, NY, USA).

\section{Results}

Baseline characteristics of all patients and controls are listed in Table 1. ${ }^{19}$

Of the 58 patients recruited, 46 (79\%) returned for follow-up assessments. Mean age of patients was $55 \pm 13$ years. Thirty-four (59\%) were men (Table 1). Thirteen (22\%) belonged to Black (7/13) and Asian (6/13) ethnic groups. Twenty (34\%) patients required non-invasive ventilation or intubation. Median duration of hospitalization was 9 days (IQR 5-17). The first assessment took place at a median interval of 2.3 months (IQR 2.1-2.5) from disease onset and second took place at $6 \cdot 0$ months (IQR 6.0 - 6.8).

On admission, all patients had a raised CRP (>10mg/L), 47\% had lymphopenia, and 21\% were anaemic. By 6 months, CRP was raised in 13\%, compared to none in controls $(P=0 \cdot 076)$, lymphocyte count normalized, and the proportion of those with anaemia was comparable to controls (11\% versus $13 \%, P=1 \cdot 0)$ (Table 2).

As previously reported, troponin on admission (measured in 38 patients) was abnormal in three (5\%) patients. By 2-3 and 6 months, none had elevated high-sensitivity troponin levels $(>34 \mathrm{ng} / \mathrm{L})$.

Only four patients had NT-proBNP measured during admission. At 2-3 months, this was elevated in $11(20 \%)$, reducing to eight (17\%) patients at 6 months versus $11 \%$ in controls $(P=0 \cdot 52)$.

\section{Electrocardiography}


medRxiv preprint doi: https://doi.org/10.1101/2021.08.03.21260940; this version posted August 5, 2021. The copyright holder for this preprint (which was not certified by peer review) is the author/funder, who has granted medRxiv a license to display the preprint in perpetuity.

It is made available under a CC-BY 4.0 International license .

ECG analysis revealed atrial fibrillation in one patient at both assessments, with all other study participants (both patients and controls) demonstrating sinus rhythm.

Prevalence of bundle branch block, ST-segment elevation/depression and T wave inversion did not differ between patients (on both visits) and controls $(P>0.05$ for all variables).

\section{Symptom burden}

Symptom prevalence in patients and controls are listed in Table 3. As a whole, $98 \%$ had one or more symptoms (cardiopulmonary and non-cardiopulmonary) at 2-3 months from infection, reducing to $89 \%$ by 6 months. Prevalence of cardiopulmonary symptoms (chest pain, palpitations, syncope, dyspnoea or dizziness) in patients was $83 \%$ at 2-3 months and dropped to $53 \%$ at 6 months $(P=0 \cdot 0001)$. At 6 months, symptoms of breathlessness (MRC) and fatigue (FSS) were worse in patients than controls (MRC grade $\geq 2: 57 \%$ vs $10 \%$, $P<0 \cdot 0001$; Mean FSS $\geq 4: 44 \%$ vs $17 \%, P=0 \cdot 023$, Table 3).

\section{Serial Cardiac Imaging}

Left ventricular (LV) volumes, mass, and function were not different between patients (at 2-3 months and 6 months) and controls (Table 4). At 6 months, two (4.5\%) patients had an LV ejection fraction (LVEF) just below the cut-off of 50\% (49.6 and 49.8\%). Those with severe illness had lower LVEF at 6 months than other patients $(60 \cdot 8 \pm 6 \cdot 6 \%$ vs $64 \cdot 8 \pm 6 \cdot 5 \%, P=0 \cdot 049)$. None of the patients had a history of pre-existing cardiac failure.

Right ventricular (RV) volumes, mass and function did not differ between patients (at 2-3 months and 6 months) and controls (Table 4). In patients, indexed RV end-diastolic volume decreased (mean difference $-4.3 \mathrm{mls} / \mathrm{m}^{2}, P=0 \cdot 005$ ) and function (RVEF) increased (mean difference $+3 \cdot 2 \%, P=0 \cdot 0003$ ) from $2-3$ months to 6 months (Figure 1). At 6 months, RVEF tended to be lower in patients with severe illness $(58 \cdot 5 \pm 5 \cdot 1 \%$ vs $62 \cdot 1 \pm 6 \cdot 9 \%, P=0 \cdot 055)$. 
Basal and mid-ventricular native $\mathrm{T}_{1}$ (a biomarker sensitive to inflammation) values were higher in patients than controls (Table 4). By 6 months, myocardial native $\mathrm{T}_{1}$ decreased and was no longer different from control $\mathrm{T}_{1}$ (Table 4; Figure 1).

Native $T_{2}$ (a biomarker sensitive to oedema) was not significantly different between patients and controls.

Extracellular volume fraction (ECV, a biomarker sensitive to diffuse fibrosis) did not differ between patients and controls. In patients, slice-averaged ECV decreased (mean difference $1 \cdot 13 \%, P=0 \cdot 005)$ from $2-3$ months to 6 months post-infection.

LGE (measured as \% of myocardial volume, a biomarker of focal fibrosis) was slightly higher in patients than controls at 2-3 months $(P=0 \cdot 023)$. By 6 months, this did not differ from controls $(P=0.62)$. There were six patients with LGE in a myocarditis pattern and one with evidence of subendocardial infarction (elevated troponin during admission). None of the patients satisfied the updated Lake Louise criteria $^{20}$ for active myocarditis (increased native $\mathrm{T}_{1} / \mathrm{LGE}$ and increased native $\mathrm{T}_{2}$ ) at 6 months.

\section{Lung imaging and functional assessment}

At 2-3 months, $60 \%$ of patients had lung parenchymal abnormalities, becoming less extensive (Table 4) with time, but were still more common compared to controls at 6 months $(P<0 \cdot 0001)$, Forty percent of patients had lung parenchymal abnormalities involving more than half the lung at 3 months. This reduced to $9 \%$ by six months.

At 2-3 months, patients had lower $\mathrm{FEV}_{1}$ and FVC compared to controls but most values remained within the normal range (Table 5). At 6 months, $\mathrm{FEV}_{1}$ was no longer different from controls $(P=0 \cdot 10)$, whereas FVC remained slightly lower $(P=0 \cdot 024)$. Reduced gas transfer $\left(\mathrm{DL}_{\mathrm{CO}}<80 \%\right.$ predicted) and reduced accessible lung volume $\left(\mathrm{V}_{\mathrm{A}}\right)$ were seen in 24 patients (52\%). Reduced transfer coefficient for carbon monoxide $\left(\mathrm{K}_{\mathrm{co}}\right)$ was present in six patients 
medRxiv preprint doi: https://doi.org/10.1101/2021.08.03.21260940; this version posted August 5, 2021. The copyright holder for this preprint (which was not certified by peer review) is the author/funder, who has granted medRxiv a license to display the preprint in perpetuity.

It is made available under a CC-BY 4.0 International license.

(13\%). Patients with parenchymal abnormalities had lower DLco compared to those without (77\% vs $91 \%, P=0 \cdot 009)$. DLco was not significantly different in patients with severe illness at admission versus non-severe patients $(77 \cdot 4 \%$ vs $84 \cdot 5 \%, P=0 \cdot 15)$.

\section{Serial Cardiopulmonary Exercise Testing}

As previously reported, patients had reduced peak oxygen consumption $\left(\mathrm{VO}_{2}\right)$ at 2-3 months. By 6 months, this improved but was still reduced relative to controls (Table 6, Figure 2).

Maximal test criteria consisted of a respiratory exchange ratio $\geq 1 \cdot 1$ and plateau in oxygen uptake. ${ }^{21}$ At 2-3 months, $49 \%$ of patients had submaximal tests (versus $15 \%$ of controls, $P=0 \cdot 003)$. By 6 months, this prevalence reduced to $26 \%(P=0 \cdot 37$ for comparison with controls).

In those with a maximal test, maximal $\mathrm{VO}_{2}$ was lower in patients at 2-3 months but was no longer so by 6 months ( $P=0 \cdot 12$ for comparison with controls).

The ventilatory equivalent for carbon dioxide $\left(\mathrm{VE} / \mathrm{VCO}_{2}\right)$ slope, a marker of ventilatory efficiency, was abnormal in patients at 2-3 months and improved by 6 months $(P=0.033)$. In spite of this, the $\mathrm{VE} / \mathrm{VCO}_{2}$ slope remained borderline abnormal (median 31.3 (IQR 28.634.5)) versus controls (median 28.2 (IQR 26.7-30.0, P=0.002)). Reduced ventilatory efficiency had little effect on exercise capacity, with respiratory limitation (defined as a breathing reserve of less than $20 \%$ at peak exertion) only occurring in $6 \%$ and $5 \%$ of patients at 2-3 and 6 months, respectively. This did not differ from controls $(4 \%, P=1 \cdot 0)$.

At 2-3 months, oxygen $\left(\mathrm{O}_{2}\right)$ pulse in maximal tests (a surrogate measure of exercise stroke volume) was lower in patients versus controls and was accompanied by earlier attainment of the anaerobic threshold (AT). By 6 months, $\mathrm{O}_{2}$ pulse improved and became comparable to controls ( $95 \%$ of predicted vs $103 \%$ of predicted, $P=0.13$ ). Despite improvement in the AT, 
medRxiv preprint doi: https://doi.org/10.1101/2021.08.03.21260940; this version posted August 5, 2021. The copyright holder for this preprint (which was not certified by peer review) is the author/funder, who has granted medRxiv a license to display the preprint in perpetuity.

It is made available under a CC-BY 4.0 International license.

occurring later during exercise, it remained different from controls (42\% of predicted $\mathrm{VO}_{2} \max$ vs $47 \%$ of predicted $\mathrm{VO}_{2} \max , P=0 \cdot 041$, Table 6).

Heart rate recovery (HRR) in the first minute following exercise cessation was slower in patients compared to controls (16.6 vs 21.9 beats, $P=0 \cdot 018)$. By 6 months, HRR improved significantly $(22 \cdot 2$ beats, $P=0 \cdot 001)$, and became comparable to controls $(P=0 \cdot 67)$. The severity of illness during admission was not associated with a reduction in peak or maximal oxygen consumption at 2-3 months and 6 months ( $P>0 \cdot 20$ for all comparisons).

\section{Relationship between symptoms and cardiopulmonary health}

At 6 months from infection, neither CMR nor pulmonary function or CPET parameters associated with cardiopulmonary symptoms (Figure 3) or breathlessness (Supplementary Material, p8). Longitudinal improvement in CMR and CPET parameters did not associate with improvement in cardiopulmonary symptoms from 2-3 months to 6 months $(P>0.05)$. There was no correlation between the extent of lung abnormalities on MRI, lung function parameters $\left(\mathrm{FEV}_{1}, \mathrm{FVC}, \mathrm{FEV}_{1} / \mathrm{FVC}, \mathrm{DLco}\right)$ and breathlessness scores (Supplementary Material, p5). The dissociation between physiological measurements and symptoms were further highlighted by the fact that of the twenty patients who did not report significant breathlessness (MRC grade <2) at 6 months, 55\% had abnormal gas transfer (DLco <80\% predicted).

\section{Discussion}

The main findings from our study are as follows: First, serial measures of cardiopulmonary health on CMR in moderate to severe COVID-19 improve over time. Second, exercise tolerance in patients recovers at 6 months post-infection but is still abnormal in some when compared to controls, due to muscular fatigue and weakness. Third, although cardiopulmonary symptom burden improves, more than half the patients remain 
symptomatic, and neither CMR nor pulmonary function or CPET measures associate with persistent symptom burden.

Since the start of the pandemic, several studies have harnessed the power of CMR to better understand the mechanisms underlying myocardial injury associated with COVID-19. ${ }^{6,22}$ Prevalence estimates of injury have varied due to differences in cohort characteristics and methodologies used. In the largest CMR follow-up study of patients with elevated troponin, Kotecha and colleagues observed that up to $49 \%$ of patients have evidence of either myocarditis or myocardial ischemia/infarction.$^{22}$ By contrast, similar-sized studies of younger athletes ${ }^{23}$ and older individuals ${ }^{6}$ with milder infections (predominantly nonhospitalised) have reported variable estimates of myocardial injury (ranging from $1.5 \%$ to 70\%). The present study is unique to others in the literature, as we prospectively recruited hospitalised COVID-19 patients and risk factor matched controls (who served as our reference) and longitudinally evaluated changes in CMR myocardial tissue characteristics in patients. Here, we show that whilst there were some patients with abnormal myocardial native $\mathrm{T}_{1}$ (a marker of oedema and inflammation) at 2-3 months, native $\mathrm{T}_{1}$ normalized in the majority by 6 months and was accompanied by a decrease in extracellular volume. These findings highlight two important points. The first is that early tissue abnormalities on CMR are likely due to dynamic alterations in the extracellular environment (hyperaemia ${ }^{24}$ or changes in extracellular proteins/matrix) influenced by circulating cytokines and importantly, not explained by comorbidities alone. This is in line with recent studies that have also demonstrated temporal changes (improvement) in inflammatory cytokines (IL-1, IL-2, IL-6, IL-18, TNF, IFNL1) in COVID-19 patients on serial assessments. ${ }^{25,26}$ The second is that cardiac health is restored in the majority of patients by 6 months. Only two patients had borderline low LV function, RV parameters were normal and there were no cases of active myocarditis (as per the updated Lake Louise criteria ${ }^{20}$ ). These findings are in keeping with 
the low prevalence (7\%) of cardiac dysfunction (defined by levels of NT-BNP) reported by a large UK-wide prospective follow-up study of post-hospitalised COVID-19 patients by Evans and colleagues. ${ }^{27}$

Exercise intolerance is common among patients recovering from coronavirus infections (SARS, MERS, and COVID-19). ${ }^{7,8,28,29}$ We had previously shown that at 2-3 months ${ }^{8}$, CPET revealed a number of abnormalities in patients. By 6 months, many of these parameters improved, though $\mathrm{VE} / \mathrm{VCO}_{2}$ slope, AT, and frequency of submaximal tests were still abnormal in patients. Of importance, cardiopulmonary limitations were not felt to be the main driver of exercise intolerance by 6 months as reduced peak oxygen consumption was only seen in symptom-limited submaximal tests. Other CPET studies of COVID-19 patients have also demonstrated a high proportion of submaximal tests. ${ }^{30}$ In one study, direct assessment of maximum muscle strength using dominant leg extension independently predicted peak oxygen consumption in patients following COVID-19. ${ }^{7}$ Taken together, these findings strongly suggest that muscular conditioning and fitness are important determinants of exercise tolerance and highlight the role of dedicated rehabilitation in augmenting recovery.

Postural orthostatic tachycardia and other manifestations of dysautonomia have frequently been described among patients post-COVID-19. ${ }^{31,32}$ Here, we showed that at 2-3 months, heart rate recovery, an indirect measure of autonomic health, was impaired in patients compared to controls. ${ }^{33}$ By six months, heart rate recovery improved, implying that dysautonomia may be transient and does spontaneously recover in some patients.

An interesting observation from serial CPET assessments was that $\mathrm{O}_{2}$ pulse, a marker of exertional stroke volume, was reduced in patients at 2-3 months and normalized by 6 months. Reduced $\mathrm{O}_{2}$ pulse has also been observed in a recent study by Baratto et al., ${ }^{34}$ where impaired tissue oxygen extraction has been implicated. Increased pulmonary vascular resistance (PVR) 
can also explain the reduced $\mathrm{O}_{2}$ pulse and may occur secondary to SARS-CoV-2 associated endothelial cell injury, impaired vasodilation, ${ }^{35}$ and/or persistent thrombo-embolic manifestations. ${ }^{36}$ Given that the RV is extremely sensitive to changes in PVR, the observed improvement in $\mathrm{O}_{2}$ pulse and $\mathrm{RV}$ function by 6 months could reflect restoration of pulmonary vascular homeostasis in patients.

As the COVID-19 pandemic has progressed, our understanding of the long-term effects of SARS-CoV-2 infection has evolved. ${ }^{37-39}$ Multiple studies ${ }^{5,27}$ have demonstrated that some patients recovering from COVID-19 experience a diverse range of persistent symptoms months beyond infection, commonly referred to as "long haul COVID" or "post-COVID-19 syndrome". ${ }^{39,40}$ In the present study, 1 in 2 patients reported persistent cardiopulmonary symptoms ((chest pain, palpitations, syncope, dyspnoea or dizziness)) at 6 months, despite an improvement in symptoms from 3 months. Neither CMR nor CPET or pulmonary function measures were associated with enduring symptoms. These findings highlight the reduced yield of standard clinical investigations in elucidating a cause for persistent symptoms and the need to explore other mechanisms (sarcopenia, muscle weakness, neurohormonal factors, autoantibodies, nociceptive alterations, mast cell activation syndrome) that may be relevant. ${ }^{41-45}$ Another important finding from this study is that more than half the patients who were asymptomatic had impaired DLco at 6 months, implying that physiological recovery may not be reliably captured by subjective measures of cardiopulmonary health. Further efforts are needed to better understand the determinants of impaired DLco and persistent parenchymal abnormalities associated with COVID-19, as we seek to develop effective treatments that could potentially reverse the long-term sequelae of COVID-19.

Although the sample size of this study is small, it has many strengths. To our knowledge, this is the first study to comprehensively (cardiopulmonary imaging, static physiology, wholebody exercise testing, patient health questionnaires) evaluate the longitudinal trajectory of 
cardiopulmonary abnormalities on CMR and CPET in patients at 3 and 6 months. From a diagnostic perspective, our study provides important insight into the lack of association between symptoms and results from standard clinical investigations. The longitudinal design and incorporation of risk factor matched control group clarified the relevance of some early abnormalities. While it was difficult to exclude significant inducible ischemia, none of the patients stopped their CPET because of angina or ischemic ECG changes. Arterial blood gas sampling or echocardiography during CPET were lacking and did not permit assessment of tissue oxygen extraction, cardiac output during exercise and pulmonary dead space. Not all patients came back for follow-up assessments (due to work commitments or had moved abroad; see supplement for details) which could in turn bias prevalence estimates in this study. However, this would not affect the relationship between symptoms and objective measures of cardiopulmonary health.

\section{Conclusion}

Our study provides novel insights into the trajectory of cardiopulmonary symptoms and abnormalities on serial CMR, spirometry and CPET in patients. At 6 months, cardiac abnormalities on CMR improved in the majority of patients and were not different to matched controls. Parenchymal abnormalities, lung function impairment and CPET improved but were still abnormal relative to controls. Nearly half the patients continue to experience symptoms at 6 months. There was a surprising dissociation between persistent cardiopulmonary symptoms and CMR/CPET parameters, underscoring the need to examine alternative mechanisms for symptom persistence in patients. 


\section{Declaration of interests}

MC reports a grant from the NIHR Oxford Biomedical Research Centre. EMT reports a grant from the NIHR Oxford Biomedical Research Centre and is a shareholder in Perspectum. AL is a shareholder in Perspectum. SKP has a US patent (6)1/387,591 licensed to Siemens and US patents 61/630,508 and 61-630,510 licensed to Perspectum. VMF reports grants from the British Heart Foundation and the National Institute Health Research Oxford Biomedical Research Centre. SN reports grants from the NIHR Oxford Biomedical Research Centre and UK Research and Innovation and is a shareholder in Perspectum. SN was a board member and consultant to Perspectum until 2019. SN has US patents 61/630,508 and 61-630,510 licensed to Perspectum. BR reports grants from the Oxford British Heart Foundation Centre for Research Excellence, the NIHR Oxford Biomedical Research Centre and the United Kingdom Research Innovation Award. All other authors do not have relationships with industry or funding sources to declare.

\section{Acknowledgements}

The authors' work was supported by the NIHR Oxford and Oxford Health Biomedical Research Centre, Oxford British Heart Foundation (BHF) Centre of Research Excellence, United Kingdom Research Innovation and Wellcome Trust. This project is part of a tier 3 study (C-MORE) within the collaborative research programme entitled PHOSP-COVID Posthospitalization COVID-19 study: a national consortium to understand and improve long-term health outcomes. Funded by the Medical Research Council and Department of Health and Social Care/National Institute for Health Research Grant (MR/V027859/1) ISRCTN number 10980107.

This work also arises from one of the national "COVID-19 Cardiovascular Disease Flagship Projects" designated by the NIHR-BHF Cardiovascular Partnership.

The sponsors played no role in the design of the study; collection, analysis and interpretation of data; in writing the manuscript, and in the decision to submit the paper for publication. The views expressed are those of the authors and not necessarily those of the National Health Service, NIHR, or the United Kingdom Department of Health.

All authors had full access to all the data in the study and accept responsibility to submit for publication.

We thank our participants and their families who have given their time to help others understand the medium to long-term effects of COVID-19. We are grateful to the University of Oxford and Oxford University Hospital Trust for their support of this study. We would like to acknowledge OCMR staff, Ms Hanan Lamlum, Ms Rebecca Mills, Ms Polly Whitworth, Ms Claudia Nunes, Ms Harriet Nixon, Ms Liliana Da Silva Rodrigues, Ms Kinga Varnai and Ms Catherine Krasopoulos for their help with this work. We acknowledge the support of Siemens in providing WIP 1048 for cardiac $\mathrm{T}_{1}$ mapping. 
medRxiv preprint doi: https://doi.org/10.1101/2021.08.03.21260940; this version posted August 5, 2021. The copyright holder for this preprint (which was not certified by peer review) is the author/funder, who has granted medRxiv a license to display the preprint in perpetuity.

It is made available under a CC-BY 4.0 International license.

\section{Data sharing statement}

The data underlying this article will be shared on reasonable request to the corresponding author, subject to institutional and ethical committee approvals. 
medRxiv preprint doi: https://doi.org/10.1101/2021.08.03.21260940; this version posted August 5, 2021. The copyright holder for this preprint (which was not certified by peer review) is the author/funder, who has granted medRxiv a license to display the preprint in perpetuity.

It is made available under a CC-BY 4.0 International license .

\section{References}

2 1. Wang C, Horby PW, Hayden FG, Gao GF. A novel coronavirus outbreak of global

3 health concern. Lancet 2020; 395(10223): 470-3.

42 2. Hoffmann M, Kleine-Weber H, Schroeder S, et al. SARS-CoV-2 Cell Entry Depends

5 on ACE2 and TMPRSS2 and Is Blocked by a Clinically Proven Protease Inhibitor. Cell 2020;

6 181(2): 271-80 e8.

7 3. Ashraf UM, Abokor AA, Edwards JM, et al. SARS-CoV-2, ACE2 expression, and

8 systemic organ invasion. Physiol Genomics 2021; 53(2): 51-60.

9 4. Ranard LS, Fried JA, Abdalla M, et al. Approach to Acute Cardiovascular

10 Complications in COVID-19 Infection. Circ Heart Fail 2020; 13(7): e007220.

11 5. Huang C, Huang L, Wang Y, et al. 6-month consequences of COVID-19 in patients

12 discharged from hospital: a cohort study. Lancet 2021; 397(10270): 220-32.

13 6. Puntmann VO, Carerj ML, Wieters I, et al. Outcomes of Cardiovascular Magnetic

14 Resonance Imaging in Patients Recently Recovered From Coronavirus Disease 2019

15 (COVID-19). JAMA Cardiology 2020.

16 7. Clavario P, De Marzo V, Lotti R, et al. Assessment of functional capacity with

17 cardiopulmonary exercise testing in non-severe COVID-19 patients at three months follow-

18 up. medRxiv 2020.

19 8. Raman B, Cassar MP, Tunnicliffe EM, et al. Medium-term effects of SARS-CoV-2

20 infection on multiple vital organs, exercise capacity, cognition, quality of life and mental

21 health, post-hospital discharge. EClinicalMedicine 2021; 31: 100683.

22 9. World Health Organisation. COVID-19 Therapeutic Trial Synopsis 02/08/2020

23 Accessed Aug 2, 2020. https://www.who.int/blueprint/priority-diseases/key-action/COVID-

24 19_Treatment_Trial_Design_Master_Protocol_synopsis_Final_18022020.pdf (accessed

$2502 / 08 / 20202020)$.

26 10. Prineas RJ, Crow RS, Zhang Z-M. The Minnesota code manual of

27 electrocardiographic findings : including measurement and comparison with the Novacode ;

28 standards and procedures for ECG measurement in epidemiologic and clinical trials. 2nd ed. /

29 Ronald J. Prineas, Richard S. Crow, Zhu-Ming Zhang. ed. London: Springer; 2010.

30 11. Kroenke K, Spitzer RL, Williams JB. The PHQ-15: validity of a new measure for

31 evaluating the severity of somatic symptoms. Psychosom Med 2002; 64(2): 258-66. 
medRxiv preprint doi: https://doi.org/10.1101/2021.08.03.21260940; this version posted August 5, 2021. The copyright holder for this preprint (which was not certified by peer review) is the author/funder, who has granted medRxiv a license to display the preprint in perpetuity.

It is made available under a CC-BY 4.0 International license .

32 12. Bestall JC, Paul EA, Garrod R, Garnham R, Jones PW, Wedzicha JA. Usefulness of

33 the Medical Research Council (MRC) dyspnoea scale as a measure of disability in patients

34 with chronic obstructive pulmonary disease. Thorax 1999; 54(7): 581-6.

35 13. Krupp LB, LaRocca NG, Muir-Nash J, Steinberg AD. The fatigue severity scale.

36 Application to patients with multiple sclerosis and systemic lupus erythematosus. Arch

37 Neurol 1989; 46(10): 1121-3.

38 14. Li K, Fang Y, Li W, et al. CT image visual quantitative evaluation and clinical

39 classification of coronavirus disease (COVID-19). Eur Radiol 2020; 30(8): 4407-16.

40 15. Graham BL, Steenbruggen I, Miller MR, et al. Standardization of Spirometry 2019

41 Update. An Official American Thoracic Society and European Respiratory Society Technical

42 Statement. Am J Respir Crit Care Med 2019; 200(8): e70-e88.

43 16. Graham BL, Brusasco V, Burgos F, et al. 2017 ERS/ATS standards for single-breath

44 carbon monoxide uptake in the lung. Eur Respir J 2017; 49(1).

45 17. Mezzani A. Cardiopulmonary Exercise Testing: Basics of Methodology and

46 Measurements. Ann Am Thorac Soc 2017; 14(Supplement_1): S3-S11.

47 18. Organisation WH. COVID-19 Therapeutic Trial Synopsis 02/08/2020 2020.

48 https://www.who.int/blueprint/priority-diseases/key-action/COVID-

49 19_Treatment_Trial_Design_Master_Protocol_synopsis_Final_18022020.pdf (accessed

50 02/08/2020 2020).

51 19. Seymour CW, Liu VX, Iwashyna TJ, et al. Assessment of Clinical Criteria for Sepsis:

52 For the Third International Consensus Definitions for Sepsis and Septic Shock (Sepsis-3).

53 JAMA 2016; 315(8): 762-74.

54 20. Ferreira VM, Schulz-Menger J, Holmvang G, et al. Cardiovascular Magnetic

55 Resonance in Nonischemic Myocardial Inflammation: Expert Recommendations. J Am Coll

56 Cardiol 2018; 72(24): 3158-76.

57 21. Levett DZH, Jack S, Swart M, et al. Perioperative cardiopulmonary exercise testing

58 (CPET): consensus clinical guidelines on indications, organization, conduct, and

59 physiological interpretation. Br J Anaesth 2018; 120(3): 484-500.

60 22. Kotecha T, Knight DS, Razvi Y, et al. Patterns of myocardial injury in recovered

61 troponin-positive COVID-19 patients assessed by cardiovascular magnetic resonance.

62 European Heart Journal 2021.

63 23. Starekova J, Bluemke DA, Bradham WS, et al. Evaluation for Myocarditis in

64 Competitive Student Athletes Recovering From Coronavirus Disease 2019 With Cardiac

65 Magnetic Resonance Imaging. JAMA cardiology 2021. 
66 24. Mahmod M, Piechnik SK, Levelt E, et al. Adenosine stress native T1 mapping in

67 severe aortic stenosis: evidence for a role of the intravascular compartment on myocardial T1

68 values. Journal of Cardiovascular Magnetic Resonance 2014; 16(1): 1-8.

69 25. Huang C, Wang Y, Li X, et al. Clinical features of patients infected with 2019 novel

70 coronavirus in Wuhan, China. The lancet 2020; 395(10223): 497-506.

71 26. Talla A, Vasaikar SV, Lemos MP, et al. Longitudinal immune dynamics of mild

72 COVID-19 define signatures of recovery and persistence. bioRxiv 2021.

73 27. Group P-CC, Evans RA, McAuley H, et al. Physical, cognitive and mental health

74 impacts of COVID-19 following hospitalisation - a multi-centre prospective cohort study.

75 medRxiv 2021: 2021.03.22.21254057.

76 28. Mohr A, Dannerbeck L, Lange TJ, et al. Cardiopulmonary exercise pattern in patients

77 with persistent dyspnoea after recovery from COVID-19. Multidisciplinary Respiratory

78 Medicine 2021; 16(1).

79 29. Ong KC, $\mathrm{Ng} \mathrm{A-K}$, Lee L-U, et al. Pulmonary function and exercise capacity in

80 survivors of severe acute respiratory syndrome. European Respiratory Journal 2004; 24(3):

$81 \quad 436-42$.

82 30. Debeaumont D, Boujibar F, Ferrand-Devouge E, et al. Cardiopulmonary Exercise

83 Testing to Assess Persistent Symptoms at 6 Months in People With COVID-19 Who

84 Survived Hospitalization-A Pilot Study. Physical Therapy 2021.

85 31. Goodman BP, Khoury JA, Blair JE, Grill MF. COVID-19 Dysautonomia. Front

86 Neurol 2021; 12: 624968.

87 32. Barizien N, Le Guen M, Russel S, Touche P, Huang F, Vallee A. Clinical

88 characterization of dysautonomia in long COVID-19 patients. Sci Rep 2021; 11(1): 14042.

89 33. Pierpont GL, Voth EJ. Assessing autonomic function by analysis of heart rate

90 recovery from exercise in healthy subjects. Am J Cardiol 2004; 94(1): 64-8.

91 34. Baratto C, Caravita S, Faini A, et al. Impact of COVID-19 on exercise

92 pathophysiology. A combined cardiopulmonary and echocardiographic exercise study. $J$ Appl

93 Physiol (1985) 2021.

94 35. Varga Z, Flammer AJ, Steiger P, et al. Endothelial cell infection and endotheliitis in

95 COVID-19. The Lancet 2020; 395(10234): 1417-8.

96 36. Nicolai L, Leunig A, Brambs S, et al. Immunothrombotic dysregulation in COVID-19

97 pneumonia is associated with respiratory failure and coagulopathy. Circulation 2020;

98 142(12): 1176-89. 
medRxiv preprint doi: https://doi.org/10.1101/2021.08.03.21260940; this version posted August 5, 2021. The copyright holder for this preprint (which was not certified by peer review) is the author/funder, who has granted medRxiv a license to display the preprint in perpetuity.

It is made available under a CC-BY 4.0 International license .

99 37. Carfì A, Bernabei R, Landi F. Persistent symptoms in patients after acute COVID-19.

100 Jama 2020; 324(6): 603-5.

101 38. Sudre CH, Murray B, Varsavsky T, et al. Attributes and predictors of long COVID.

102 Nature Medicine 2021: 1-6.

103 39. Davis HE, Assaf GS, McCorkell L, et al. Characterizing Long COVID in an

104 International Cohort: 7 Months of Symptoms and Their Impact. medRxiv 2020.

105 40. Nalbandian A, Sehgal K, Gupta A, et al. Post-acute COVID-19 syndrome. Nat Med

$1062021 ; 27(4): 601-15$.

107 41. Amenta EM, Spallone A, Rodriguez-Barradas MC, El Sahly HM, Atmar RL,

108 Kulkarni PA. Postacute COVID-19: An Overview and Approach to Classification. Open

109 Forum Infect Dis 2020; 7(12): ofaa509.

110 42. Cox LS, Bellantuono I, Lord JM, et al. Tackling immunosenescence to improve

111 COVID-19 outcomes and vaccine response in older adults. Lancet Healthy Longev 2020;

112 1(2): e55-e7.

113 43. Doykov I, Hallqvist J, Gilmour KC, Grandjean L, Mills K, Heywood WE. 'The long

114 tail of Covid-19' - The detection of a prolonged inflammatory response after a SARS-CoV-2

115 infection in asymptomatic and mildly affected patients. F1000Res 2020; 9: 1349.

116 44. McFarland AJ, Yousuf MS, Shiers S, Price TJ. Neurobiology of SARS-CoV-2

117 interactions with the peripheral nervous system: implications for COVID-19 and pain. Pain

118 Rep 2021; 6(1): e885.

119 45. Wang EY, Mao T, Klein J, et al. Diverse functional autoantibodies in patients with

120 COVID-19. Nature 2021; 595(7866): 283-8. 
Table 1. Demographics and baseline characteristics of COVID-19 patients who underwent single assessment, serial assessments (2-3 months \& 6 months) and controls.

\begin{tabular}{|c|c|c|c|c|c|c|}
\hline & $\begin{array}{c}\text { COVID-19, 2-3m } \\
(\mathrm{N}=58)\end{array}$ & $\begin{array}{c}\text { COVID-19, 6m } \\
(\mathrm{N}=46)\end{array}$ & Controls(N=30) & 2-3m vs Controls & $\begin{array}{l}P \text {-values } \\
6 \mathrm{~m} \text { vs Controls }\end{array}$ & $2-3 m$ vs $6 m$ \\
\hline \multicolumn{7}{|l|}{ General demographics } \\
\hline Age, years & $55 \cdot 4(13 \cdot 2)$ & $55 \cdot 2(13 \cdot 3)$ & $53 \cdot 9(12 \cdot 3)$ & $0 \cdot 62$ & 0.67 & $0 \cdot 96$ \\
\hline Gender & & & & $1 \cdot 00^{\mathrm{a}}$ & $0 \cdot 81^{\mathrm{a}}$ & $0.69^{\mathrm{a}}$ \\
\hline Female & $24 / 58(41.4 \%)$ & $17 / 46(37 \cdot 0 \%)$ & $12 / 30(40 \cdot 0 \%)$ & & & \\
\hline Male & $34 / 58(58 \cdot 6 \%)$ & $29 / 46(63.0 \% \%)$ & $18 / 30(60 \cdot 0 \%)$ & & & \\
\hline BMI, $\mathrm{kg} / \mathrm{m}^{2}$ & $30 \cdot 8(26 \cdot 2-36 \cdot 4)$ & $30 \cdot 6(26 \cdot 6-35 \cdot 6)$ & $27 \cdot 3(23 \cdot 1-35 \cdot 1)$ & $0 \cdot 17^{\mathrm{b}}$ & $0 \cdot 19^{\mathrm{b}}$ & $0 \cdot 91^{\mathrm{b}}$ \\
\hline Black/Asian and minority ethnic groups & $13 / 58(22 \cdot 4 \%)$ & $10 / 46(21.7 \%)$ & $1 / 30(3 \cdot 3 \%)$ & $0 \cdot 03^{\mathrm{c}}$ & $0 \cdot 04^{\mathrm{c}}$ & $1 \cdot 00^{\mathrm{a}}$ \\
\hline Current/Ex-smoker & $20 / 58(34 \cdot 5 \%)$ & $17 / 46(37 \cdot 0 \%)$ & $7 / 30(23 \cdot 3 \%)$ & $0 \cdot 34^{\mathrm{c}}$ & $0 \cdot 31^{\mathrm{c}}$ & $0 \cdot 84^{\mathrm{a}}$ \\
\hline Type 1 Diabetes & $1 / 58(1.7 \%)$ & $1 / 46(2 \cdot 2 \%)$ & $0 / 30(0 \cdot 0 \%)$ & $1 \cdot 00^{\mathrm{c}}$ & $1 \cdot 00^{\mathrm{c}}$ & $1 \cdot 00^{\mathrm{c}}$ \\
\hline Type 2 Diabetes & $8 / 58(13 \cdot 8 \%)$ & $7 / 46(15 \cdot 2 \%)$ & $3 / 30(10 \cdot 0 \%)$ & $0 \cdot 74^{\mathrm{c}}$ & $0.73^{\mathrm{c}}$ & $1 \cdot 00^{\mathrm{a}}$ \\
\hline Hypertension & $22 / 58(37.9 \%)$ & $17 / 46(37 \cdot 0 \%)$ & $9 / 30(30 \cdot 0 \%)$ & $0 \cdot 49^{\mathrm{c}}$ & $0 \cdot 62^{\mathrm{c}}$ & $1 \cdot 00^{\mathrm{a}}$ \\
\hline Coronary artery disease & $2 / 58(3.4 \%)$ & $1 / 46(2.2 \%)$ & $0 / 30(0.0 \%)$ & $0.55^{\mathrm{c}}$ & $1 \cdot 00^{\mathrm{c}}$ & $1 \cdot 00^{\mathrm{c}}$ \\
\hline Cerebrovascular Disease & $1 / 58(1.7 \%)$ & $0 / 46(0.0 \%)$ & $0 / 30(0.0 \%)$ & $1 \cdot 00^{\mathrm{c}}$ & $1 \cdot 00^{\mathrm{c}}$ & $1 \cdot 00^{\mathrm{c}}$ \\
\hline Asthma & $20 / 58(34 \cdot 5 \%)$ & $17 / 46(37.0 \%)$ & $6 / 30(20 \cdot 0 \%)$ & $0 \cdot 22^{\mathrm{c}}$ & $0 \cdot 13^{\mathrm{c}}$ & $0 \cdot 84^{\mathrm{a}}$ \\
\hline COPD & $3 / 58(5 \cdot 2 \%)$ & $2 / 46(4 \cdot 3 \%)$ & $0 / 30(0.0 \%)$ & $0.55^{\mathrm{c}}$ & $0 \cdot 51^{\mathrm{c}}$ & $1 \cdot 00^{\mathrm{c}}$ \\
\hline Previous cancer & $2 / 58(3.4 \%)$ & $2 / 46(4 \cdot 3 \%)$ & $3 / 30(10 \cdot 0 \%)$ & $0 \cdot 33^{\mathrm{c}}$ & $0 \cdot 38^{\mathrm{c}}$ & $1 \cdot 00^{\mathrm{c}}$ \\
\hline Depression & $3 / 58(5 \cdot 2 \%)$ & $3 / 46(6 \cdot 5 \%)$ & $1 / 30(3.3 \%)$ & $1.00^{\mathrm{c}}$ & $1 \cdot 00^{\mathrm{c}}$ & $1.00^{\mathrm{c}}$ \\
\hline \multicolumn{7}{|l|}{ Admission details } \\
\hline Median length of stay, days & $8 \cdot 5(5 \cdot 0-17 \cdot 0)$ & $9 \cdot 0(5 \cdot 0-17 \cdot 5)$ & .. & .. & .. & $0 \cdot 85^{\mathrm{b}}$ \\
\hline
\end{tabular}




\begin{tabular}{|c|c|c|}
\hline Readmitted & $10 / 58(17 \cdot 2 \%)$ & $9 / 46(19 \cdot 6 \%)$ \\
\hline Required ITU admission & $21 / 58(36 \cdot 2 \%)$ & $17 / 46(37 \cdot 0 \%)$ \\
\hline \multicolumn{3}{|l|}{ qSOFA } \\
\hline 0 & $17 / 58(29 \cdot 3 \%)$ & $15 / 46(32 \cdot 6 \%)$ \\
\hline 1 & $38 / 58(65 \cdot 5 \%)$ & $29 / 46(63.0 \%)$ \\
\hline 2 & $3 / 58(5 \cdot 2 \%)$ & $2 / 46(4 \cdot 3 \%)$ \\
\hline 3 & $0 / 58(0 \cdot 0 \%)$ & $0 / 46$ \\
\hline \multicolumn{3}{|c|}{ Ordinal scale for clinical improvement (WHO) } \\
\hline 1 & $0 / 58(0 \cdot 0 \%)$ & $0 / 46$ \\
\hline 2 & $4 / 58(6.9 \%)$ & $3 / 46(6 \cdot 5 \%)$ \\
\hline 3 & $22 / 58(37.9 \%)$ & $16 / 46(34.8 \%)$ \\
\hline 4 & $5 / 58(8 \cdot 6 \%)$ & $4 / 46(8.7 \%)$ \\
\hline 5 & $15 / 58(25 \cdot 9 \%)$ & $12 / 46(26 \cdot 1 \%)$ \\
\hline 6 & $7 / 58(12 \cdot 1 \%)$ & $6 / 46(13 \cdot 0 \%)$ \\
\hline 7 & $5 / 58(8 \cdot 6 \%)$ & $5 / 46(10.9 \%)$ \\
\hline \multicolumn{3}{|c|}{ Signs and symptoms on admission } \\
\hline Fever & $51 / 58(87.9 \%)$ & $40 / 46(87 \cdot 0 \%)$ \\
\hline Malaise & $51 / 58(87.9 \%)$ & $41 / 46(89 \cdot 1 \%)$ \\
\hline Shortness of breath & $51 / 58(87.9 \%)$ & $41 / 46(89 \cdot 1 \%)$ \\
\hline Cough & $35 / 58(60 \cdot 3 \%)$ & $26 / 46(56 \cdot 5 \%)$ \\
\hline Dysgeusia & $29 / 58(50 \cdot 0 \%)$ & $21 / 46(45 \cdot 7 \%)$ \\
\hline Anosmia & $26 / 58(44 \cdot 8 \%)$ & $20 / 46(43.5 \%)$ \\
\hline Diarrhoea & $17 / 58(29 \cdot 3 \%)$ & $13 / 46(28 \cdot 3 \%)$ \\
\hline Chest pain & $16 / 58(27 \cdot 6 \%)$ & $13 / 46(28 \cdot 3 \%)$ \\
\hline Headache & $13 / 58(22 \cdot 4 \%)$ & $12 / 46(26 \cdot 0 \%)$ \\
\hline Vomiting & $9 / 58(15 \cdot 5 \%)$ & $6 / 46(13.0 \%)$ \\
\hline
\end{tabular}

$0 \cdot 48^{\mathrm{a}}$
$0 \cdot 55^{\mathrm{a}}$
$0 \cdot 94^{\mathrm{d}}$


$1 \cdot 00^{\mathrm{d}}$




$0 \cdot 56^{\mathrm{a}}$
$0 \cdot 55^{\mathrm{a}}$
$0 \cdot 55^{\mathrm{a}}$
$0 \cdot 42^{\mathrm{a}}$
$0 \cdot 70^{\mathrm{a}}$
$1 \cdot 00^{\mathrm{a}}$
$1 \cdot 00^{\mathrm{a}}$
$1 \cdot 00^{\mathrm{a}}$
$0 \cdot 82^{\mathrm{a}}$
$0 \cdot 79^{\mathrm{a}}$ 


\begin{tabular}{|c|c|c|c|c|c|c|}
\hline \multicolumn{7}{|l|}{ Treatment } \\
\hline Oxygen replacement & $54 / 58(93 \cdot 1 \%)$ & $43 / 46(93.5 \%)$ & .. &.. & .. & $1 \cdot 00^{\mathrm{c}}$ \\
\hline Nasal cannula & $14 / 58(24 \cdot 1 \%)$ & $10 / 46(21 \cdot 7 \%)$ & .. &.. & .. & $1 \cdot 00^{\mathrm{d}}$ \\
\hline Simple face mask & $7 / 58(12 \cdot 1 \%)$ & $5 / 46(10 \cdot 8 \%)$ & .. & .. & .. & \\
\hline Venturi face mask & $6 / 58(10 \cdot 3 \%)$ & $5 / 46(10 \cdot 8 \%)$ & .. &.. & .. & \\
\hline High flow oxygen delivery & $7 / 58(12 \cdot 1 \%)$ & $5 / 46(10 \cdot 8 \%)$ &.$\cdot$ &.$\cdot$ & .. & \\
\hline CPAP & $8 / 58(13.8 \%)$ & $7 / 46(15 \cdot 2 \%)$ & .. &.. & .. & \\
\hline Intubation & $12 / 58(20 \cdot 7 \%)$ & $11 / 46(23.9 \%)$ &.$\cdot$ &.$\cdot$ & .. & \\
\hline ECMO & $0 / 58(0 \%)$ & $0 / 46$ & .. &.. & .. & \\
\hline Inotropic support & $4 / 58(6.9 \%)$ & $4 / 46(8.7 \%)$ & .. &.. & .. & $0.73^{c}$ \\
\hline Renal replacement therapy & $2 / 58(3.4 \%)$ & $2 / 46(4 \cdot 3 \%)$ & .. &.. & .. & $1 \cdot 00^{\mathrm{c}}$ \\
\hline Antibiotics & $57 / 58(98 \cdot 3 \%)$ & $45 / 46(97 \cdot 8 \%)$ & .. & .. & .. & $1.00^{\mathrm{c}}$ \\
\hline Antivirals & $4 / 58(6.9 \%)$ & $2 / 46(4 \cdot 3 \%)$ & .. &.. & .. & $0.69^{c}$ \\
\hline Steroids & $16 / 58(27 \cdot 6 \%)$ & $14 / 46(30 \cdot 4 \%)$ & .. &.. & .. & $0 \cdot 83^{\mathrm{a}}$ \\
\hline \multicolumn{7}{|l|}{ Acute organ injury } \\
\hline Acute liver injurye & $18 / 58(31.0 \%)$ & $18 / 46(39 \cdot 1 \%)$ & .. &.. & .. & $0 \cdot 41^{\mathrm{a}}$ \\
\hline Acute kidney injury ${ }^{\mathrm{f}}$ & $6 / 58(10 \cdot 3 \%)$ & $6 / 46(13 \cdot 0 \%)$ & .. & .. & .. & $0.76^{\mathrm{a}}$ \\
\hline Acute cardiac injury ${ }^{\mathrm{g}}$ & $3 / 58(5 \cdot 2 \%)$ & $0 / 46$ & .. & .. & .. & $0 \cdot 25^{\mathrm{c}}$ \\
\hline Pulmonary embolism & $7 / 58(12 \cdot 1 \%)$ & $6 / 46(13 \cdot 0 \%)$ & .. &.. & .. & $1 \cdot 00^{\mathrm{a}}$ \\
\hline Central & $1 / 58(1.7 \%)$ & $0 / 46$ &.. &.. & .. & $1.00^{\mathrm{c}}$ \\
\hline Peripheral & $6 / 58(10 \cdot 3 \%)$ & $6 / 46(13 \cdot 0 \%)$ & .. &.. & .. & $0.76^{\mathrm{a}}$ \\
\hline \multicolumn{7}{|c|}{ 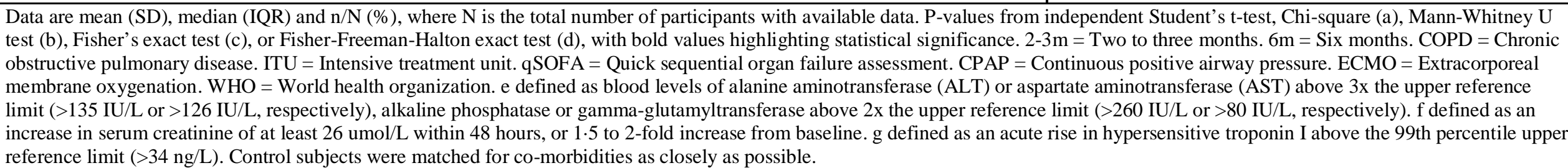 } \\
\hline
\end{tabular}


Table 2. Blood test results and symptom prevalence for patients with COVID-19 and controls.

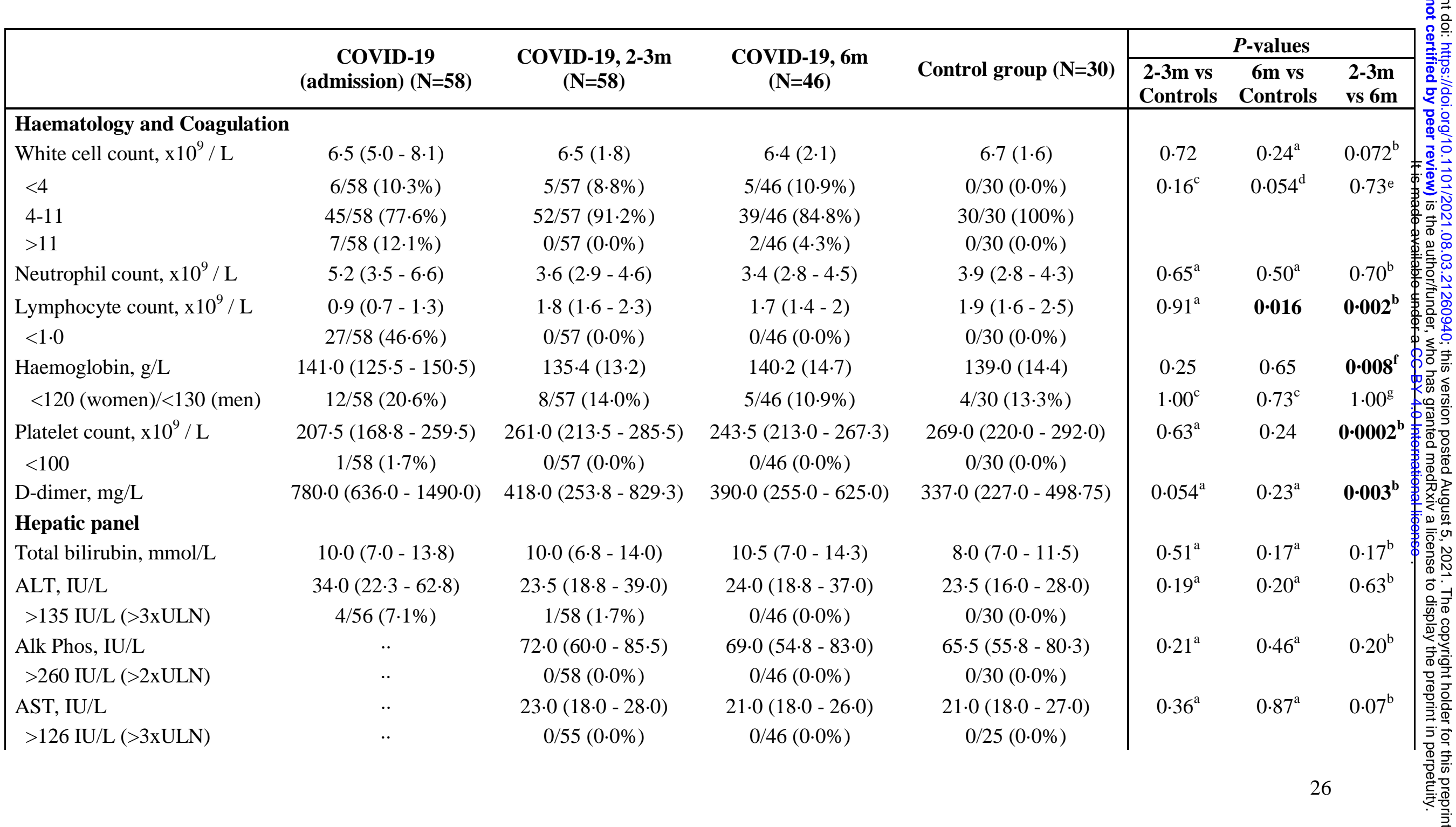




\begin{tabular}{|c|c|c|c|c|c|c|c|}
\hline GGT, IU/L & .. & $33 \cdot 0(21 \cdot 8-52 \cdot 3)$ & $30 \cdot 5(22 \cdot 0-42 \cdot 3)$ & $29 \cdot 0(18 \cdot 5-47 \cdot 5)$ & $0 \cdot 25^{\mathrm{a}}$ & $0 \cdot 74^{\mathrm{a}}$ & $\mathbf{0 \cdot 0 0 2 ^ { b }}$ \\
\hline >80 IU/L (>2xULN) & .. & $6 / 54(11 \cdot 1 \%)$ & $1 / 46(4 \cdot 0 \%)$ & $1 / 25(4 \%)$ & $0 \cdot 42^{\mathrm{c}}$ & & \\
\hline \multicolumn{8}{|c|}{ Renal function and electrolytes } \\
\hline Potassium, mmol/L & $3 \cdot 8(3 \cdot 7-4 \cdot 1)$ & $3 \cdot 9(0 \cdot 3)$ & $3 \cdot 9(0 \cdot 3)$ & $3 \cdot 9(0 \cdot 3)$ & $0 \cdot 92$ & 0.23 & $0.55^{\mathrm{f}}$ \\
\hline Sodium, mmol/L & $136 \cdot 0(2 \cdot 9)$ & $141 \cdot 0(139 \cdot 0-141 \cdot 3)$ & $141 \cdot 0(139 \cdot 0-142 \cdot 0)$ & $140 \cdot 0(139 \cdot 0-141 \cdot 0)$ & $0 \cdot 12^{\mathrm{a}}$ & $0 \cdot 050^{\mathrm{a}}$ & $0 \cdot 11^{\mathrm{b}}$ \\
\hline Creatinine, umol/L & $75 \cdot 5(69 \cdot 0-91 \cdot 0)$ & $69 \cdot 5(60 \cdot 0-79 \cdot 3)$ & $74 \cdot 5(64 \cdot 8-86 \cdot 0)$ & $79 \cdot 0(63 \cdot 0-89 \cdot 0)$ & $0 \cdot 16^{\mathrm{a}}$ & $0 \cdot 64^{\mathrm{a}}$ & $0 \cdot 012^{b}$ \\
\hline$\leq 133$ & $55 / 58(94 \cdot 8 \%)$ & $57 / 58(98 \cdot 3 \%)$ & $44 / 46(95 \cdot 7 \%)$ & $30 / 30(100 \%)$ & & & \\
\hline$>133$ & $3 / 58(5 \cdot 2 \%)$ & $1 / 58(1.7 \%)$ & $2 / 46(4 \cdot 3 \%)$ & $0 / 30(0 \%)$ & & & \\
\hline \multicolumn{8}{|l|}{$\mathrm{eGFR}, \mathrm{ml} / \mathrm{min} / 1 \cdot 73 \mathrm{~m}^{2}$} \\
\hline$\geq 90$ & $31 / 58(53 \cdot 4 \%)$ & $38 / 58(65 \cdot 5 \%)$ & $26 / 46(56 \cdot 5 \%)$ & $17 / 30(56 \cdot 7 \%)$ & $0.53^{\mathrm{d}}$ & $0 \cdot 74^{\mathrm{d}}$ & $0 \cdot 22^{\mathrm{e}}$ \\
\hline $60-89$ & $21 / 58(36 \cdot 2 \%)$ & $17 / 58(29 \cdot 3 \%)$ & $18 / 46(39 \cdot 1 \%)$ & $13 / 30(43 \cdot 3 \%)$ & & & \\
\hline $45-59$ & $3 / 58(5 \cdot 2 \%)$ & $1 / 58(1.7 \%)$ & $0 / 46(0.0 \%)$ & $0 / 30(0 \cdot 0 \%)$ & & & \\
\hline $30-44$ & $2 / 58(3.4 \%)$ & $2 / 58(3.4 \%)$ & $2 / 46(3.4 \%)$ & $0 / 30(0 \cdot 0 \%)$ & & & \\
\hline $15-29$ & $1 / 58(1.7 \%)$ & $0 / 58(0 \cdot 0 \%)$ & $0 / 46(0 \cdot 0 \%)$ & $0 / 30(0 \cdot 0 \%)$ & & & \\
\hline$<15$ & $0 / 58(0.0 \%)$ & $0 / 58(0.0 \%)$ & $0 / 46(0 \cdot 0 \%)$ & $0 / 30(0 \cdot 0 \%)$ & & & \\
\hline \multicolumn{8}{|l|}{ Inflammatory markers } \\
\hline C-reactive protein, $\mathrm{mg} / \mathrm{L}$ & $119 \cdot 1(75.9-185 \cdot 5)$ & $2 \cdot 0(0 \cdot 9-5 \cdot 0)$ & $1 \cdot 7(0 \cdot 9-5 \cdot 6)$ & $1 \cdot 2(0 \cdot 7-2 \cdot 6)$ & $0 \cdot 058^{\mathrm{a}}$ & $0 \cdot 23^{\mathrm{a}}$ & $0.98^{\mathrm{b}}$ \\
\hline$>10$ & $58 / 58(100 \%)$ & $4 / 58(6 \cdot 9 \%)$ & $6 / 46(13 \cdot 0 \%)$ & $0 / 30(0 \cdot 0 \%)$ & $0 \cdot 29^{c}$ & $0.076^{\mathrm{c}}$ & $0 \cdot 45^{\mathrm{g}}$ \\
\hline Procalcitonin, ug/L & .. & $0.020(0.020-0.040)$ & $0.020(0.010-0.030)$ & $0.02(0.020-0.030)$ & $0 \cdot 80^{\mathrm{a}}$ & $0 \cdot 22^{\mathrm{a}}$ & $0.083^{b}$ \\
\hline \multicolumn{8}{|c|}{ Heart failure, cardiac injury } \\
\hline NT-proBNP, ng/L & .. & $56 \cdot 8(32 \cdot 3-113 \cdot 6)$ & $56 \cdot 3(31 \cdot 2-98 \cdot 3)$ & $48 \cdot 1(23 \cdot 0-88 \cdot 4)$ & $0 \cdot 22^{\mathrm{a}}$ & $0 \cdot 50^{\mathrm{a}}$ & $0 \cdot 20^{\mathrm{b}}$ \\
\hline$\geq 125$ & & $11 / 56(19.6 \%)$ & $8 / 46(17 \cdot 4 \%)$ & $3 / 28(10 \cdot 7 \%)$ & $0 \cdot 37^{\mathrm{c}}$ & $0 \cdot 52^{c}$ & $0 \cdot 75^{\mathrm{g}}$ \\
\hline Troponin I, ng/L & .. & $2 \cdot 0(2 \cdot 0-3 \cdot 0)$ & $2 \cdot 0(2 \cdot 0-4 \cdot 0)$ & $2 \cdot 0(2 \cdot 0-3 \cdot 0)$ & $0 \cdot 49^{\mathrm{a}}$ & $0 \cdot 27^{\mathrm{a}}$ & $0 \cdot 14^{\mathrm{b}}$ \\
\hline$>34$ & & $0 / 58(0 \cdot 0 \%)$ & $0 / 46(0 \cdot 0 \%)$ & $0 / 27(0 \cdot 0 \%)$ & & & \\
\hline
\end{tabular}




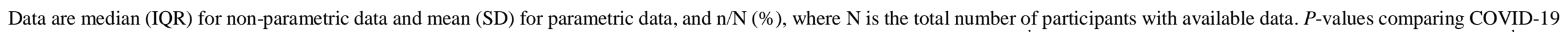

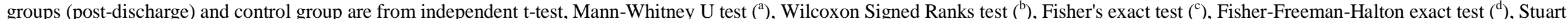

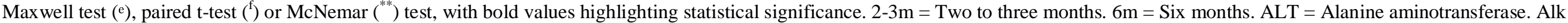

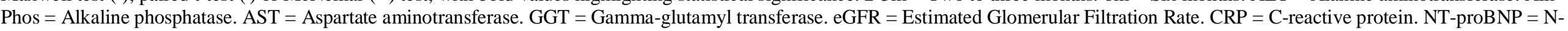
terminal pro-brain natriuretic peptide 
Table 3. Symptom prevalence, Fatigue Severity Score and MRC dyspnoea scale in patients at follow-up and controls.

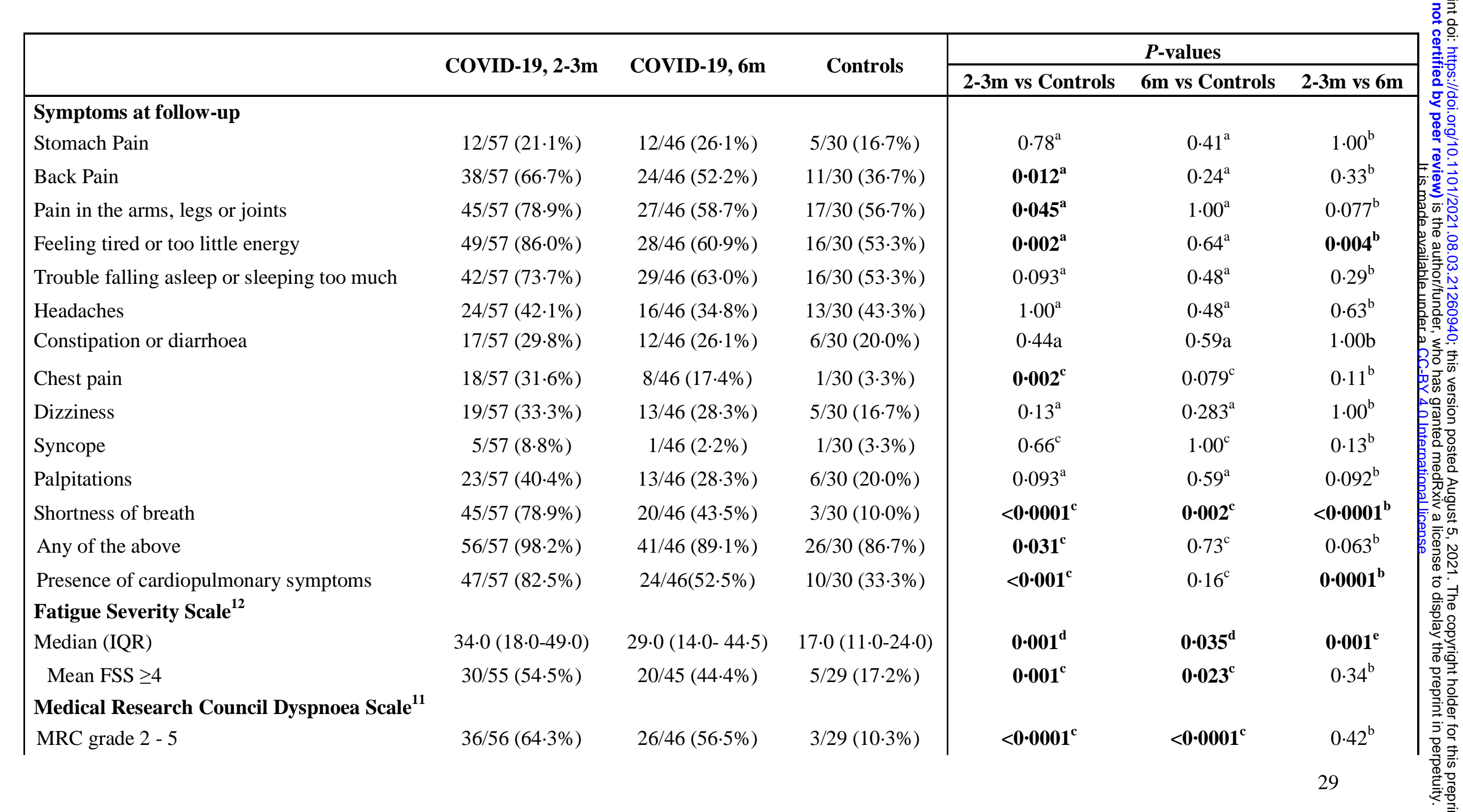




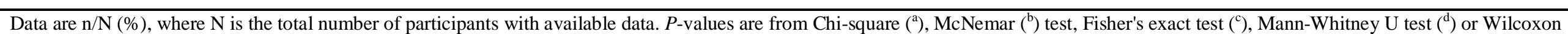

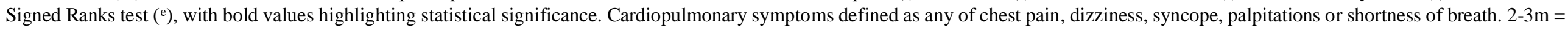
Two to three months. $6 \mathrm{~m}=$ Six months. MRC $=$ Medical research council. FSS $=$ Fatigue severity scale. 
Table 4. Cardiopulmonary MRI parameters in patients and controls.

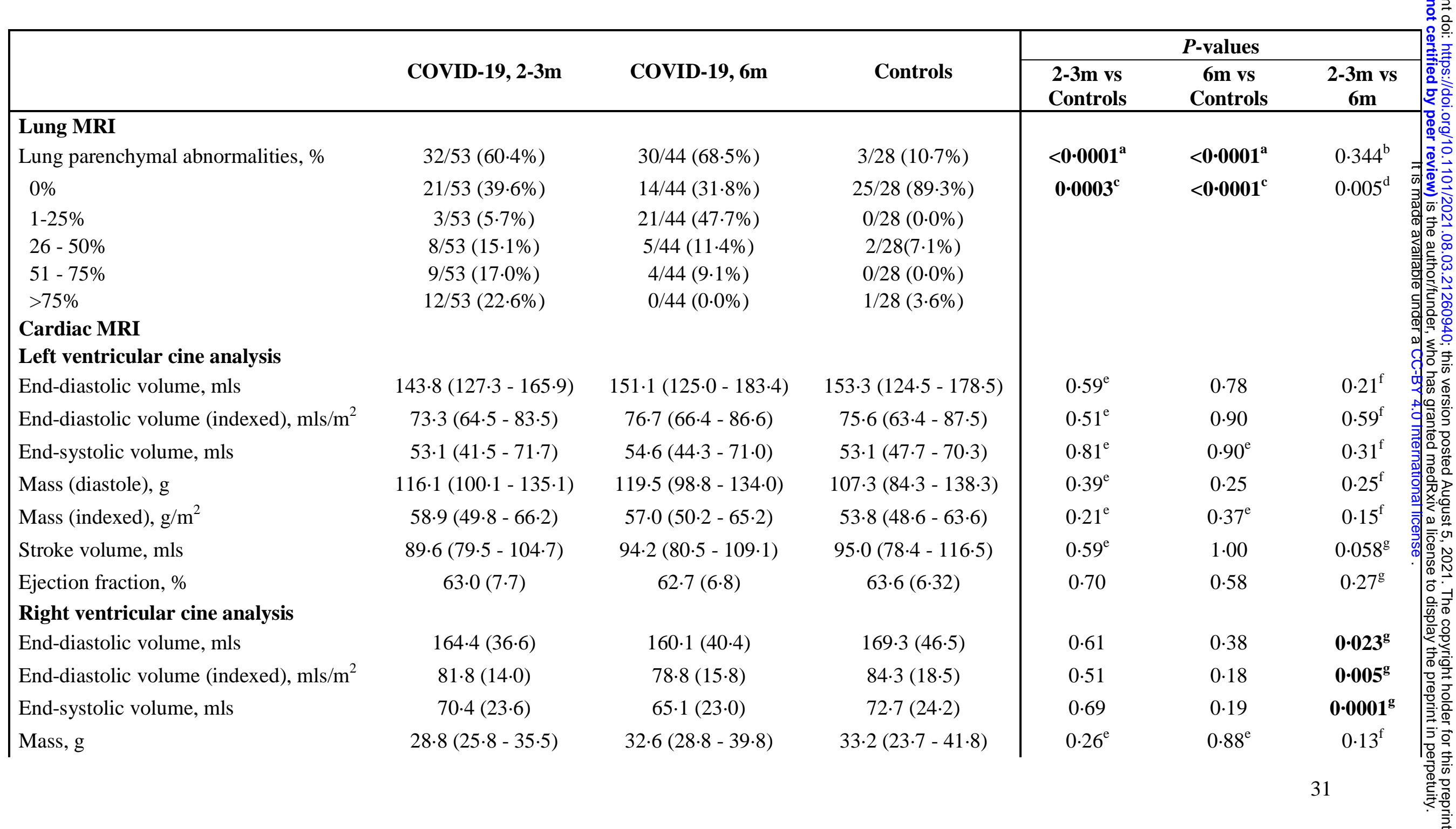




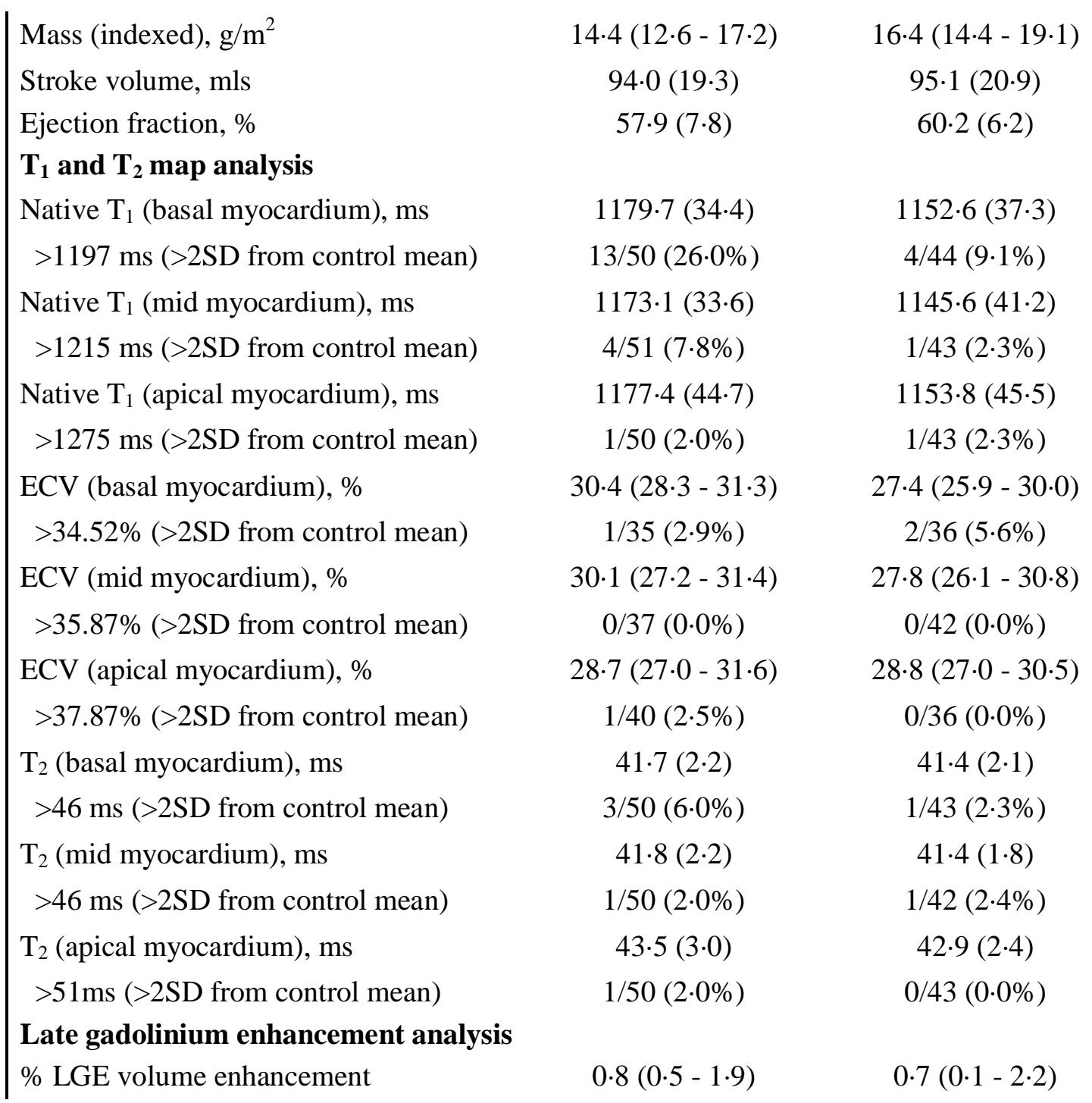

$\begin{array}{cc}14 \cdot 4(12 \cdot 6-17 \cdot 2) & 16 \cdot 4(14 \cdot 4-19 \cdot 1) \\ 94 \cdot 0(19 \cdot 3) & 95 \cdot 1(20 \cdot 9) \\ 57 \cdot 9(7 \cdot 8) & 60 \cdot 2(6 \cdot 2) \\ & \\ 1179 \cdot 7(34 \cdot 4) & 1152 \cdot 6(37 \cdot 3) \\ 13 / 50(26 \cdot 0 \%) & 4 / 44(9 \cdot 1 \%) \\ 1173 \cdot 1(33 \cdot 6) & 1145 \cdot 6(41 \cdot 2) \\ 4 / 51(7 \cdot 8 \%) & 1 / 43(2 \cdot 3 \%) \\ 1177 \cdot 4(44 \cdot 7) & 1153 \cdot 8(45 \cdot 5) \\ 1 / 50(2 \cdot 0 \%) & 1 / 43(2 \cdot 3 \%) \\ 30 \cdot 4(28 \cdot 3-31 \cdot 3) & 27 \cdot 4(25 \cdot 9-30 \cdot 0) \\ 1 / 35(2 \cdot 9 \%) & 2 / 36(5 \cdot 6 \%) \\ 30 \cdot 1(27 \cdot 2-31 \cdot 4) & 27 \cdot 8(26 \cdot 1-30 \cdot 8) \\ 0 / 37(0 \cdot 0 \%) & 0 / 42(0 \cdot 0 \%) \\ 28 \cdot 7(27 \cdot 0-31 \cdot 6) & 28 \cdot 8(27 \cdot 0-30 \cdot 5) \\ 1 / 40(2 \cdot 5 \%) & 0 / 36(0 \cdot 0 \%) \\ 41 \cdot 7(2 \cdot 2) & 41 \cdot 4(2 \cdot 1) \\ 3 / 50(6 \cdot 0 \%) & 1 / 43(2 \cdot 3 \%) \\ 41 \cdot 8(2 \cdot 2) & 41 \cdot 4(1 \cdot 8) \\ 1 / 50(2 \cdot 0 \%) & 1 / 42(2 \cdot 4 \%) \\ 43 \cdot 5(3 \cdot 0) & 42 \cdot 9(2 \cdot 4) \\ 1 / 50(2 \cdot 0 \%) & 0 / 43(0 \cdot 0 \%) \\ 0 \cdot 8(0 \cdot 5-1 \cdot 9) & 0 \cdot 7(0 \cdot 1-2 \cdot 2)\end{array}$

\begin{tabular}{c|}
$16 \cdot 7(13 \cdot 9-19 \cdot 3)$ \\
$96 \cdot 6(25 \cdot 6)$ \\
$57 \cdot 6(6 \cdot 0)$ \\
$1149 \cdot 3(24)$ \\
$1 / 28(3 \cdot 7 \%)$ \\
$1150 \cdot 2(32 \cdot 4)$ \\
$0 / 28(0 \%)$ \\
$1168 \cdot 3(53 \cdot 2)$ \\
$1 / 28(3 \cdot 6 \%)$ \\
$28 \cdot 3(26 \cdot 8-31 \cdot 5)$ \\
$0 / 21(0 \cdot 0 \%)$ \\
$29 \cdot 4(27 \cdot 1-30 \cdot 7)$ \\
$1 / 23(4 \cdot 3 \%)$ \\
$29 \cdot 7(27 \cdot 2-31 \cdot 5)$ \\
$1 / 23(4 \cdot 3 \%)$ \\
$41 \cdot 6(2 \cdot 2)$ \\
$1 / 28(3 \cdot 6 \%)$ \\
$41 \cdot 1(2 \cdot 3)$ \\
$1 / 28(3 \cdot 6 \%)$ \\
$43 \cdot 7(3 \cdot 5)$ \\
$1 / 28(3 \cdot 6 \%)$ \\
$0 \cdot 6(0 \cdot 3-1)$
\end{tabular}

$$
\begin{gathered}
0 \cdot 19^{\mathrm{e}} \\
0 \cdot 61 \\
0 \cdot 85 \\
\mathbf{0 \cdot 0 0 0 1} \\
\mathbf{0 \cdot 0 1 5 ^ { \mathrm { a } }} \\
\mathbf{0 \cdot 0 0 4} \\
0 \cdot 29^{\mathrm{a}} \\
0 \cdot 42 \\
1 \cdot 00^{\mathrm{a}} \\
0 \cdot 12 \\
1 \cdot 00^{\mathrm{a}} \\
0 \cdot 41^{\mathrm{e}} \\
0 \cdot 38^{\mathrm{a}} \\
0 \cdot 51^{\mathrm{e}} \\
1 \cdot 00^{\mathrm{a}} \\
0 \cdot 80 \\
1 \cdot 00^{\mathrm{a}} \\
0 \cdot 21 \\
1 \cdot 00^{\mathrm{a}} \\
0 \cdot 81^{\mathrm{e}} \\
1 \cdot 00^{\mathrm{a}} \\
\mathbf{0 \cdot 0 2 3 ^ { \mathrm { e } }}
\end{gathered}
$$

\section{$0.31^{\mathrm{f}}$ \\ $0.68^{\mathrm{g}}$ \\ $\mathbf{0 \cdot 0 0 0 3}$ \\ $<0 \cdot 0001^{\text {g }}$ $0.065^{\mathrm{b}}$ \\ $<0 \cdot 0001^{\mathrm{g}}$ \\ $0.38^{\mathrm{b}}$ \\ 0.001 ${ }^{\mathrm{g}}$ \\ $1 \cdot 00^{\mathrm{b}}$ \\ 0.001 ${ }^{\mathrm{f}}$ \\ $1 \cdot 00^{\mathrm{b}}$ \\ $0 \cdot 030^{f}$ \\ $0 \cdot 32^{\mathrm{g}}$ \\ $1.00^{\mathrm{b}}$ \\ $0.71^{\mathrm{g}}$ \\ $1.00^{\mathrm{b}}$ \\ $0.50^{\mathrm{g}}$ \\ $1.00^{\mathrm{b}}$ \\ $0.51^{\mathrm{f}}$ \\ $1 \cdot 00^{\mathrm{b}}$ \\ $0 \cdot 91^{\mathrm{f}}$}




$\begin{array}{|lccc|}\text { Myocarditis pattern } & 6 / 52(11.5 \%) & 5 / 43(11.6 \%) & 2 / 28(7 \cdot 4 \%) \\ \text { Myocardial infarction } & 1 / 52(1.9 \%) & 0 / 43(0 \cdot 0 \%) & 0 / 28(0 \cdot 0 \%) \\ \text { LV/RV insertion point } & 7 / 52(13.5 \%) & 5 / 43(11.6 \%) & 1 / 28(3 \cdot 7 \%) \\ \text { Mixed } & 0 / 52(0.0 \%) & 0 / 43(0.0 \%) & 0 / 28(0 \cdot 0 \%) \\ \text { Other } & 0 / 52(0.0 \%) & 0 / 43(0.0 \%) & 0 / 28(0 \cdot 0 \%) \\ \text { Pericardial effusion }>10 \mathrm{~mm} & 1 / 52(1.9 \%) & 0 / 43(0.0 \%) & 0 / 52(0.0 \%)\end{array}$

Data are median (IQR) for non-parametric data and mean (SD) for parametric data, and $\mathrm{n} / \mathrm{N}(\%)$, where $\mathrm{N}$ is the total number of participants with available data. $P$-values are from independent $\mathrm{t}$-test Fisher's exact test $\left({ }^{\mathrm{a}}\right)$, McNemar $\left({ }^{\mathrm{b}}\right)$ test, Fisher-Freeman-Halton exact test $\left({ }^{\mathrm{C}}\right)$, Stuart-Maxwell test $\left({ }^{\mathrm{d}}\right)$, Mann-Whitney U test $\left({ }^{(}\right)$, Wilcoxon Signed Ranks test $\left({ }^{\mathrm{f}}\right)$, or paired t-test $\left({ }^{\text {(aa) }}\right)$, with bold value highlighting statistical significance. $2-3 \mathrm{~m}=$ Two to three months. $6 \mathrm{~m}=$ Six months. MRI = Magnetic resonance imaging. ECV = Extracellular volume. $\mathrm{LGE}=\mathrm{Late}$ gadolinium enhancement. 
Table 5. Spirometry and gas transfer testing results in patients at follow-up and controls.

\begin{tabular}{|c|c|c|c|c|c|c|}
\hline & \multirow{2}{*}{ COVID-19, 2-3m } & \multirow{2}{*}{ COVID-19, 6m } & \multirow{2}{*}{ Control group } & \multicolumn{3}{|c|}{$P$-values } \\
\hline & & & & 2-3m vs Controls & 6m vs Controls & $2-3 m$ vs $6 m$ \\
\hline \multicolumn{7}{|l|}{ Spirometry } \\
\hline FVC, $\%$ predicted & $108 \cdot 3(22 \cdot 8)$ & $119 \cdot 2(22 \cdot 0)$ & $131 \cdot 4(21 \cdot 8)$ & $<0 \cdot 0001$ & $0 \cdot 024$ & $<0 \cdot 0001^{\mathrm{a}}$ \\
\hline$<80 \%$ & $7 / 56(12.5 \%)$ & $0 / 46(0.0 \%)$ & $0 / 28(0.0 \%)$ & $0.090^{\mathrm{b}}$ & .. & $0 \cdot 016^{\mathrm{c}}$ \\
\hline $\mathrm{FEV}_{1}, \%$ predicted & $101 \cdot 4(19 \cdot 7)$ & $110 \cdot 7(18 \cdot 6)$ & $118 \cdot 7(22 \cdot 1)$ & $0 \cdot 0004$ & $0 \cdot 10$ & $<0 \cdot 0001^{\mathrm{a}}$ \\
\hline$<80 \%$ & $6 / 56(10.7 \%)$ & $1 / 46(2 \cdot 2 \%)$ & $1 / 28(3.6 \%)$ & $0 \cdot 42^{\mathrm{b}}$ & $1 \cdot 00^{\mathrm{b}}$ & $0.063^{c}$ \\
\hline $\mathrm{FEV}_{1} / \mathrm{FVC}$ & $0.77(0.73-0.80)$ & $0.76(0.73-0.80)$ & $0.75(0.70-0.78)$ & $0 \cdot 027^{d}$ & $0 \cdot 24$ & $0 \cdot 051^{\mathrm{a}}$ \\
\hline $\begin{array}{l}\text { Peak expiratory flow, } \% \text { predicted } \\
\text { Gas Transfer }\end{array}$ & $105 \cdot 7(27 \cdot 7)$ & $108 \cdot 8(21 \cdot 7)$ & $114 \cdot 5(24 \cdot 7)$ & $0 \cdot 16$ & $0 \cdot 31$ & $0.74^{\mathrm{a}}$ \\
\hline $\mathrm{DL}_{\mathrm{CO}}, \%$ of predicted & .. & $80 \cdot 9(16 \cdot 9)$ & .. & .. & .. & .. \\
\hline$<80 \%$ & .. & $24 / 46(52 \cdot 2 \%)$ & .. & .. & .. & .. \\
\hline $\mathrm{K}_{\mathrm{CO}}, \%$ of predicted & .. & $101 \cdot 8(18 \cdot 2)$ & .. & .. & .. & .. \\
\hline$<80 \%$ & .. & $6 / 46(13.0 \%)$ & .. & .. & .. & .. \\
\hline $\mathrm{V}_{\mathrm{a}}, \%$ of predicted & .. & $79.9(14 \cdot 7)$ & .. & .. & .. & .. \\
\hline$<80 \%$ & .. & $24 / 46(52 \cdot 2 \%)$ & .. & .. & .. & .. \\
\hline
\end{tabular}


Table 6. CPET parameters in patients at follow-up and controls.

\begin{tabular}{|c|c|c|c|c|c|c|}
\hline & \multirow[b]{2}{*}{ COVID-19, 2-3m } & \multirow[b]{2}{*}{ COVID-19, 6m } & \multirow[b]{2}{*}{ Control group } & \multicolumn{3}{|c|}{$P$-values } \\
\hline & & & & $\begin{array}{l}2-3 m \text { vs } \\
\text { Controls } \\
\end{array}$ & $\begin{array}{c}6 \mathrm{~m} \text { vs } \\
\text { Controls } \\
\end{array}$ & $\begin{array}{c}2-3 m \\
\text { vs } 6 m\end{array}$ \\
\hline \multicolumn{7}{|l|}{ Cardiopulmonary exercise testing } \\
\hline Maximal tests performed & $26 / 51(51 \cdot 0 \%)$ & $31 / 42(73 \cdot 8 \%)$ & $23 / 27(85 \cdot 2 \%)$ & $0 \cdot 003^{\mathrm{a}}$ & $0 \cdot 37^{\mathrm{a}}$ & $0 \cdot 057^{\mathrm{b}}$ \\
\hline $\mathrm{SpO}_{2}$ at peak exercise, $\%$ & $95 \cdot 0(93.8-97 \cdot 0)$ & $96 \cdot 0(95 \cdot 0-97 \cdot 0)$ & $96 \cdot 0(95 \cdot 0-98 \cdot 0)$ & $\mathbf{0 \cdot 0 0 3}{ }^{\mathrm{c}}$ & $0 \cdot 10^{\mathrm{c}}$ & $\mathbf{0} \cdot 002^{d}$ \\
\hline$<94 \%$ & $12 / 51(23 \cdot 5 \%)$ & $3 / 41(7 \cdot 3 \%)$ & $1 / 27(3 \cdot 7 \%)$ & $\mathbf{0 \cdot 0 2 8 ^ { \mathrm { a } }}$ & $1.00^{\mathrm{a}}$ & $0 \cdot 016^{b}$ \\
\hline $\mathrm{VO}_{2}$ peak (all tests), $\mathrm{mls} / \mathrm{kg} / \mathrm{min}$ & $18 \cdot 0(14 \cdot 4-21 \cdot 9)$ & $20 \cdot 5(17 \cdot 5-26 \cdot 1)$ & $28 \cdot 1(22 \cdot 1-34 \cdot 0)$ & $<0 \cdot 001^{\mathrm{c}}$ & $0 \cdot 001$ & $\mathbf{0 \cdot 0 0 1}{ }^{\mathrm{d}}$ \\
\hline $\mathrm{VO}_{2} \max$ (maximal tests), $\mathrm{mls} / \mathrm{kg} / \mathrm{min}$ & $21 \cdot 1(16 \cdot 1-27 \cdot 9)$ & $22 \cdot 7(19 \cdot 4-27 \cdot 1)$ & $28 \cdot 1(22 \cdot 1-34 \cdot 5)$ & $0 \cdot 012^{c}$ & $0 \cdot 044^{c}$ & $0 \cdot 006^{d}$ \\
\hline Anaerobic threshold, $\mathrm{mls} / \mathrm{kg} / \mathrm{min}$ & $9 \cdot 7(8 \cdot 3-10 \cdot 7)$ & $10 \cdot 4(9 \cdot 0-12 \cdot 2)$ & $11 \cdot 9(9 \cdot 3-13 \cdot 9)$ & $0 \cdot 001^{c}$ & $\mathbf{0 \cdot 0 2 3 ^ { c }}$ & $0 \cdot 018^{d}$ \\
\hline $\mathrm{VO}_{2}$ peak (all tests), $\%$ of predicted $\mathrm{VO}_{2} \max$ & $80 \cdot 5(23 \cdot 1)$ & $93 \cdot 3(29 \cdot 3)$ & $112 \cdot 7(27 \cdot 0)$ & $<0 \cdot 0001$ & $\mathbf{0 \cdot 0 0 7}$ & $0 \cdot 0001^{\mathrm{e}}$ \\
\hline$<80 \%$ & $28 / 51(54.9 \%)$ & $13 / 42(31 \cdot 0 \%)$ & $2 / 27(7 \cdot 4 \%)$ & $<0 \cdot 0001^{\mathrm{a}}$ & $\mathbf{0 \cdot 0 3 4 ^ { \mathrm { a } }}$ & $\mathbf{0} \cdot 012^{b}$ \\
\hline $\mathrm{VO}_{2} \max$ (maximal tests), $\%$ of predicted & $95 \cdot 5(19 \cdot 9)$ & $100 \cdot 7(27 \cdot 1)$ & $112 \cdot 3(27 \cdot 0)$ & $0 \cdot 016$ & $0 \cdot 12$ & $\mathbf{0 \cdot 0 0 3}$ \\
\hline$<80 \%$ & $5 / 26(19 \cdot 2 \%)$ & $6 / 31(19 \cdot 4 \%)$ & $1 / 23(4 \cdot 3 \%)$ & $0 \cdot 13^{\mathrm{a}}$ & $0 \cdot 22^{\mathrm{a}}$ & $0 \cdot 63^{\mathrm{b}}$ \\
\hline Anaerobic threshold ( $\%$ of predicted $\mathrm{VO}_{2} \max$ ) & $40 \cdot 7(36 \cdot 2-47 \cdot 5)$ & $42 \cdot 0(39 \cdot 0-51 \cdot 6)$ & $46 \cdot 8(43 \cdot 3-51 \cdot 3)$ & $0 \cdot 0005^{\mathrm{c}}$ & $0 \cdot 041^{c}$ & $\mathbf{0 \cdot 0 3 0 ^ { d }}$ \\
\hline $\mathrm{O}_{2}$ pulse, $\%$ of predicted max & $81 \cdot 8(18 \cdot 2)$ & $90 \cdot 2(28 \cdot 3)$ & $102 \cdot 8(20 \cdot 8)$ & $<0 \cdot 0001$ & $\mathbf{0 \cdot 0 2 0 ^ { c }}$ & $\mathbf{0 \cdot 0 0 3}{ }^{\mathrm{d}}$ \\
\hline $\mathrm{O}_{2}$ pulse (maximal tests), $\%$ of predicted max & $91 \cdot 4(18 \cdot 3)$ & $95 \cdot 2(26 \cdot 5)$ & $103 \cdot 3(20 \cdot 9)$ & $\mathbf{0} \cdot \mathbf{0 3 9}$ & $0 \cdot 13^{\mathrm{c}}$ & $0 \cdot 011^{\mathrm{e}}$ \\
\hline Breathing reserve, $\%$ of predicted VEmax & $44 \cdot 8(15 \cdot 3)$ & $42 \cdot 4(15 \cdot 5)$ & $40 \cdot 7(11 \cdot 0)$ & $0 \cdot 22$ & $0 \cdot 62$ & $0.71^{\mathrm{e}}$ \\
\hline$<20 \%$ & $3 / 51(5.9 \%)$ & $2 / 42(4 \cdot 8 \%)$ & $1 / 27(3 \cdot 7 \%)$ & $1.00^{\mathrm{a}}$ & $1 \cdot 00^{\mathrm{a}}$ & $1.00^{\mathrm{b}}$ \\
\hline Breathing reserve (maximal tests), \% of predicted VEmax & $34 \cdot 9(12 \cdot 1)$ & $38 \cdot 1(12 \cdot 6)$ & $38.9(9.9)$ & $0 \cdot 21$ & $0 \cdot 80$ & $0.79 e$ \\
\hline HR recovery slope (maximal tests), bpm & $16 \cdot 6(7 \cdot 1)$ & $22 \cdot 2(11 \cdot 1)$ & $21.9(7.5)$ & $0 \cdot 018$ & $0.67^{\mathrm{c}}$ & $\mathbf{0 \cdot 0 0 1} 1^{\mathrm{d}}$ \\
\hline $\mathrm{VE} / \mathrm{VCO}_{2}$ Slope & $33 \cdot 4(29 \cdot 2-40 \cdot 3)$ & $31 \cdot 3(28 \cdot 6-34 \cdot 5)$ & $28 \cdot 2(26 \cdot 7-30 \cdot 0)$ & $<0 \cdot 0001^{c}$ & $0 \cdot 002^{c}$ & $\mathbf{0} \cdot \mathbf{0 3 3}{ }^{\mathrm{d}}$ \\
\hline
\end{tabular}




\begin{tabular}{|c|c|c|c|c|}
\hline Oxygen Uptake Efficiency Slope & $2 \cdot 1(1 \cdot 7-2 \cdot 8)$ & $2 \cdot 7(2 \cdot 0-3 \cdot 2)$ & $0.065^{\mathrm{c}}$ & $0 \cdot 11^{\mathrm{d}}$ \\
\hline
\end{tabular}


A

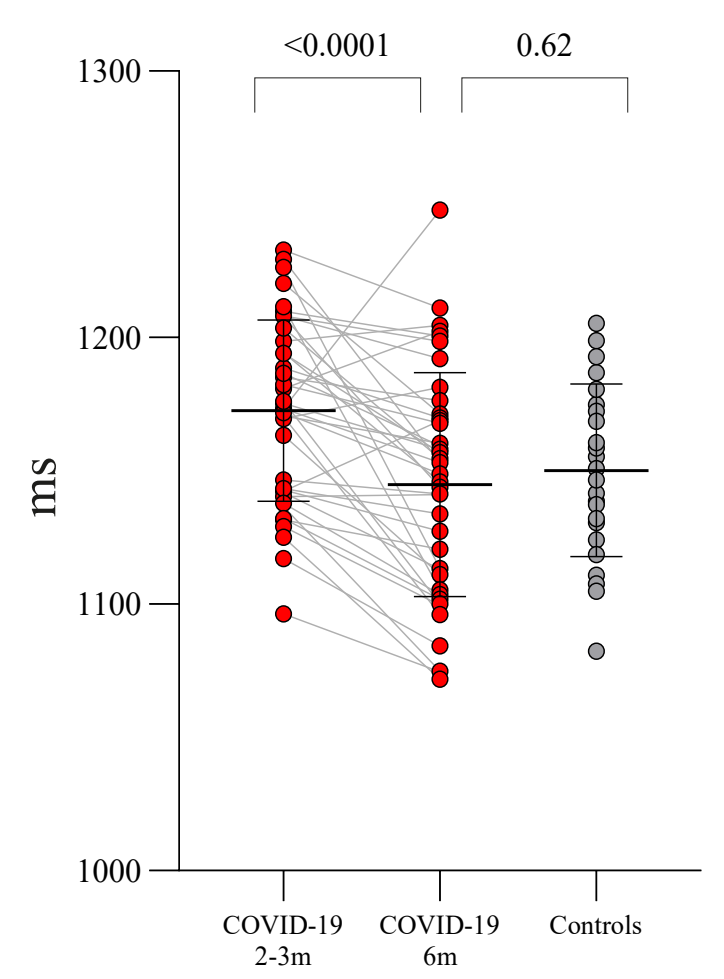

B $\quad$ Mid ECV

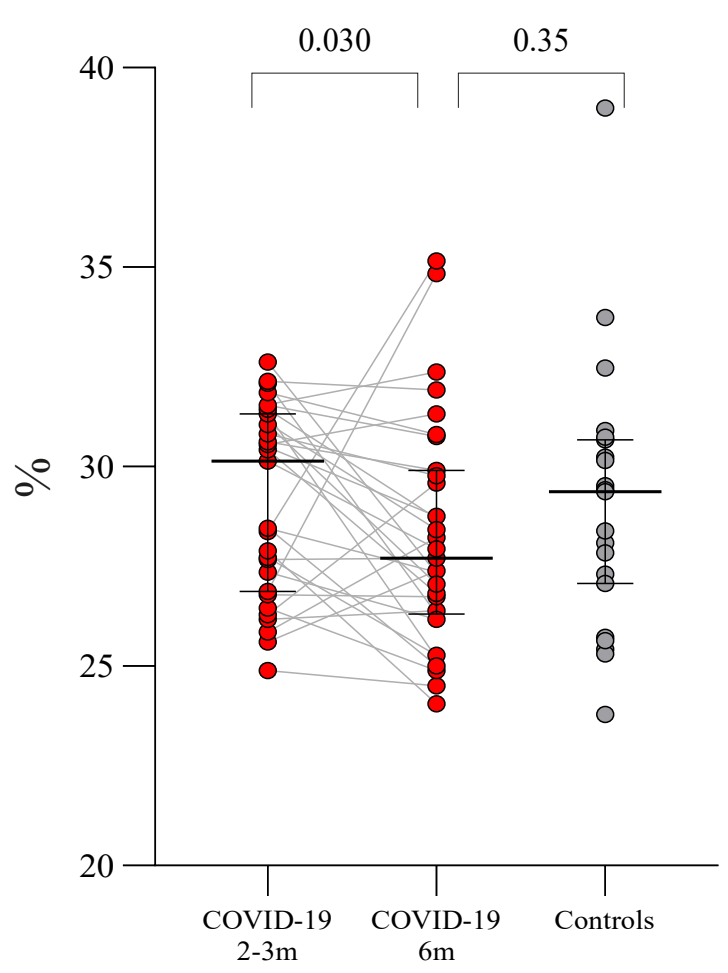

C RVEF

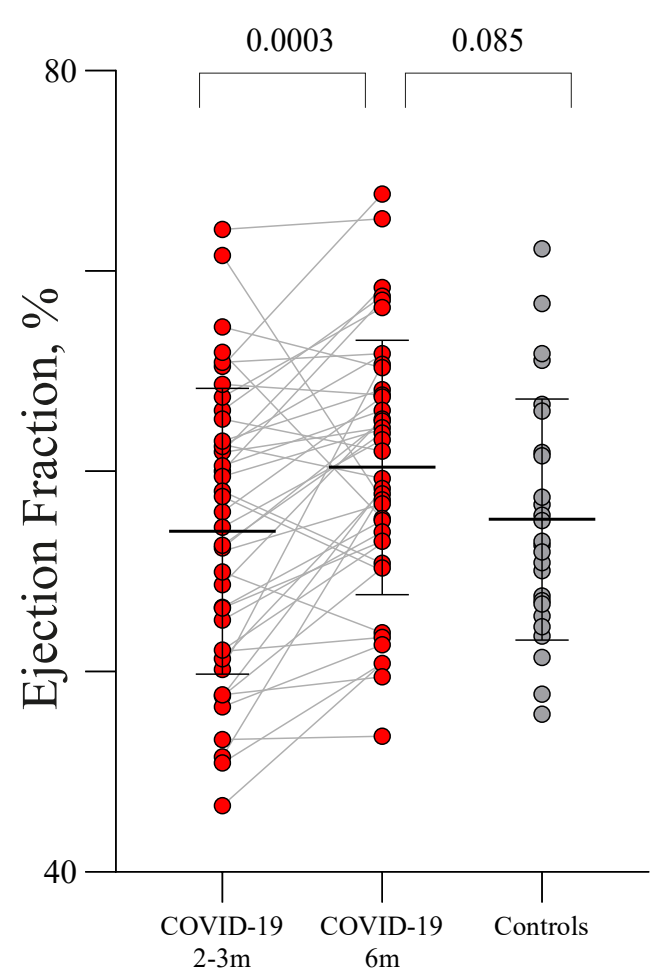

Figure 1. Serial CMR findings in previously hospitalised COVID-19 patients and controls. A: Mid ventricular native $\mathrm{T}_{1}$ in patients at 2-3 months was higher than controls, and normalized by 6 months. B: Mid ventricular extracellular volume fraction (ECV) in patients at 2-3 months was comparable to controls, but decreased in patients by 6 months. C: Right ventricular ejection fraction in patients at 2-3 months was comparable to controls, and increased by 6 months. P-values are for group differences (COVID-19 2-3 months vs COVID-19 6 months and COVID-19 6 months vs controls). 
a $\quad \mathrm{VO}_{2}$ Peak

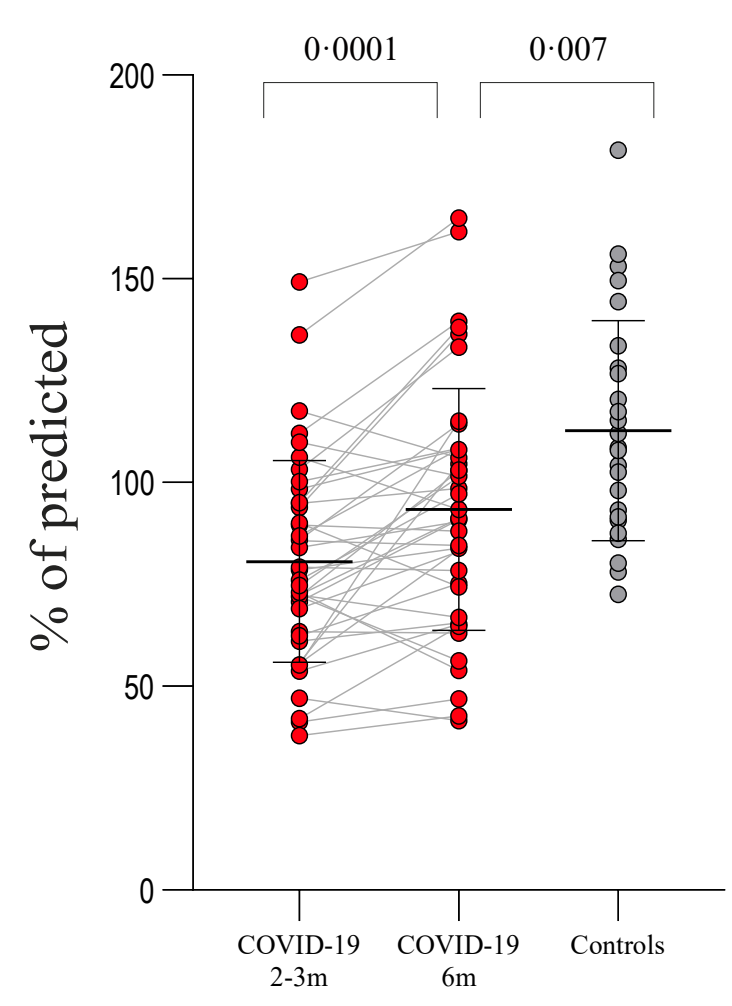

b

$\mathrm{O}_{2}$ Pulse*

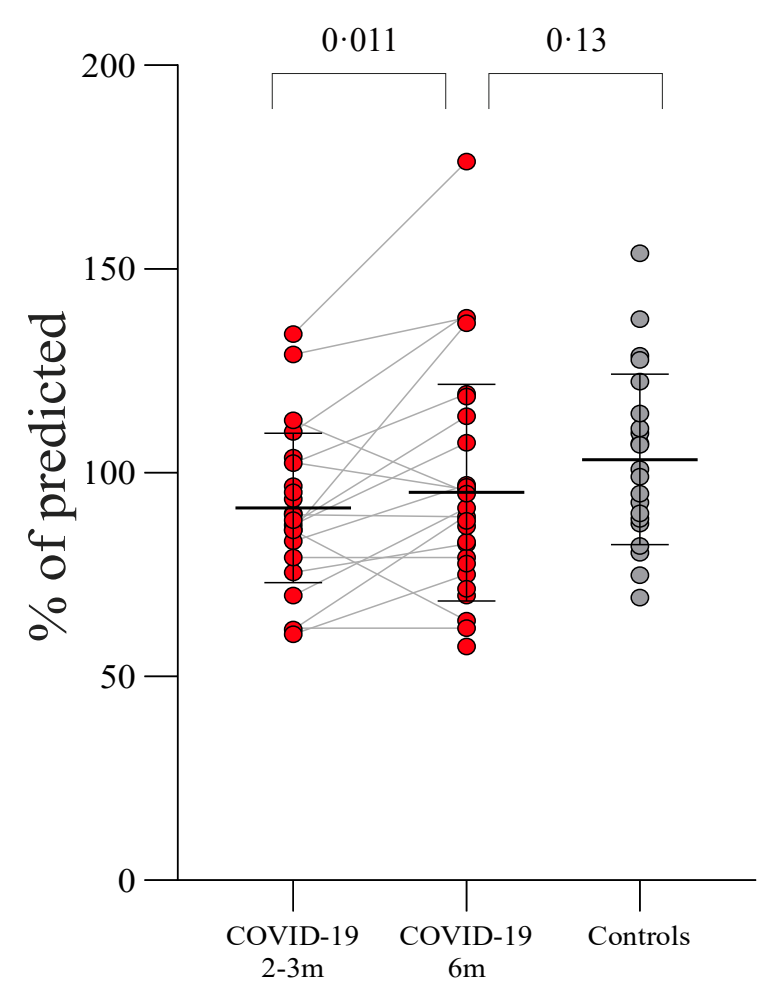

c $\quad \mathrm{VE} / \mathrm{VCO}_{2}$ Slope

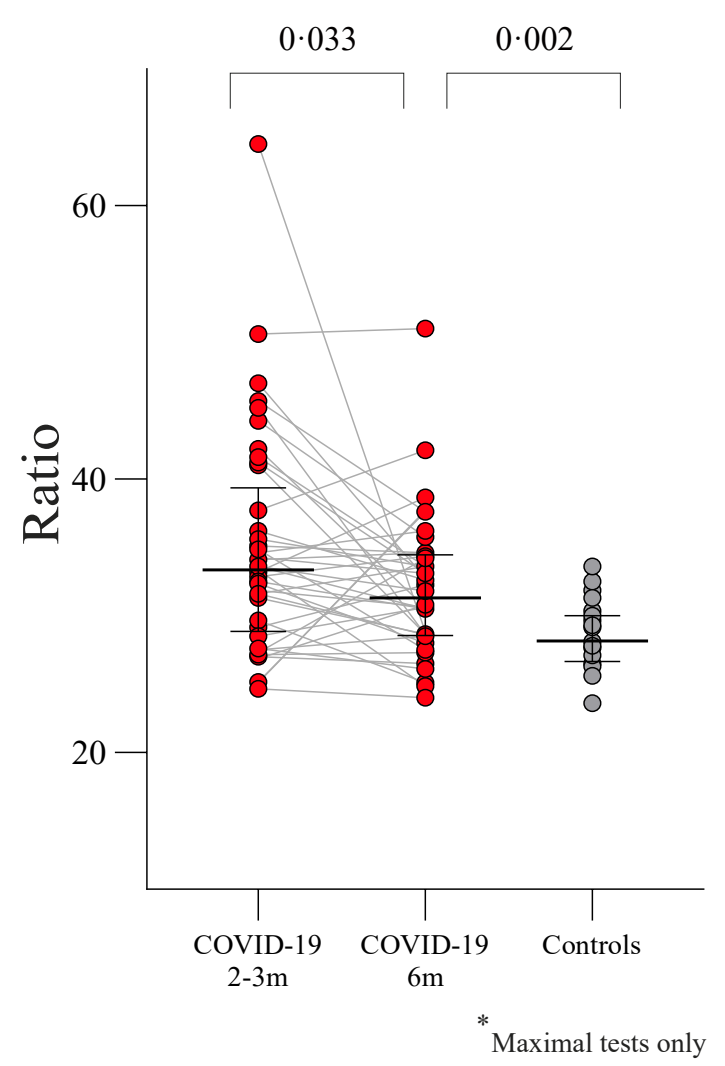

Figure 2. Serial CPET assessments in previously hospitalised COVID-19 patients and controls. A: Peak oxygen consumption (VO ${ }_{2}$ peak) in patients improved from 2-3 months to 6 months, but remained lower than controls. B: Peak oxygen pulse $\left(\mathrm{O}_{2}\right.$ pulse $)$ in patients with maximal tests at 2-3 months was lower compared to controls. By 6 months, this improved and became comparable to controls. C: The ventilatory equivalent for carbon dioxide $\left(\mathrm{VE} / \mathrm{VCO}_{2}\right)$ slope in patients improved from 2-3 months to 6 months, but remained high versus controls. P-values are for group differences (COVID-19 2-3 months vs COVID-19 6 months and COVID-19 6 months vs controls). 


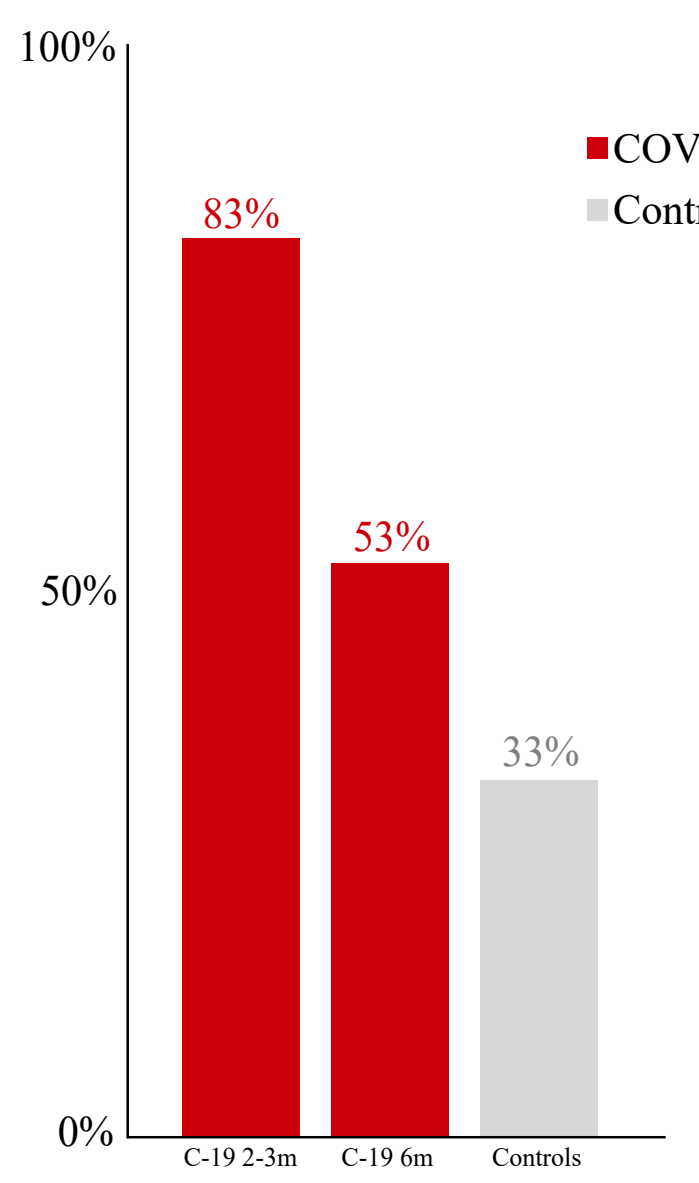

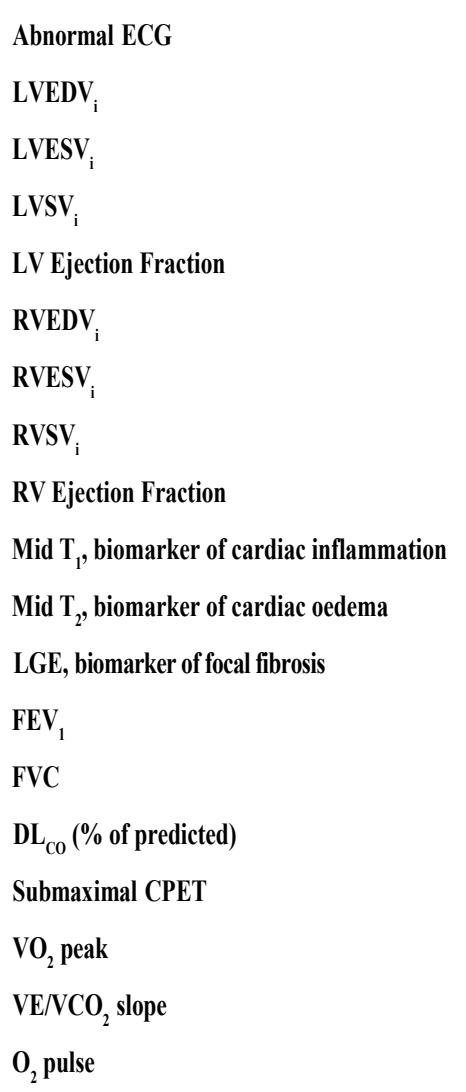

$0.49(0.13-1.79)$

$0.99(0.96-1.03)$

$0.98(0.92-1.05)$

$1.03(0.95-1.11)$

$1.10(0.92-1.01)$

$0.99(0.95-1.02)$

$0.96(0.90-1.02)$

$1.00(0.93-1.08)$

$1.10(0.99-1.22)$

$1.00(0.98-1.01)$

$0.90(0.63-1.27)$

$0.75(0.50-1.13)$

$0.62(0.29-1.33)$

$0.76(0.45-1.28)$

$1.00(0.96-1.03)$

$0.47(0.11-1.94)$

$0.49(0.16-1.50)$

$0.98(0.87-1.11)$

$0.99(0.96-1.01)$

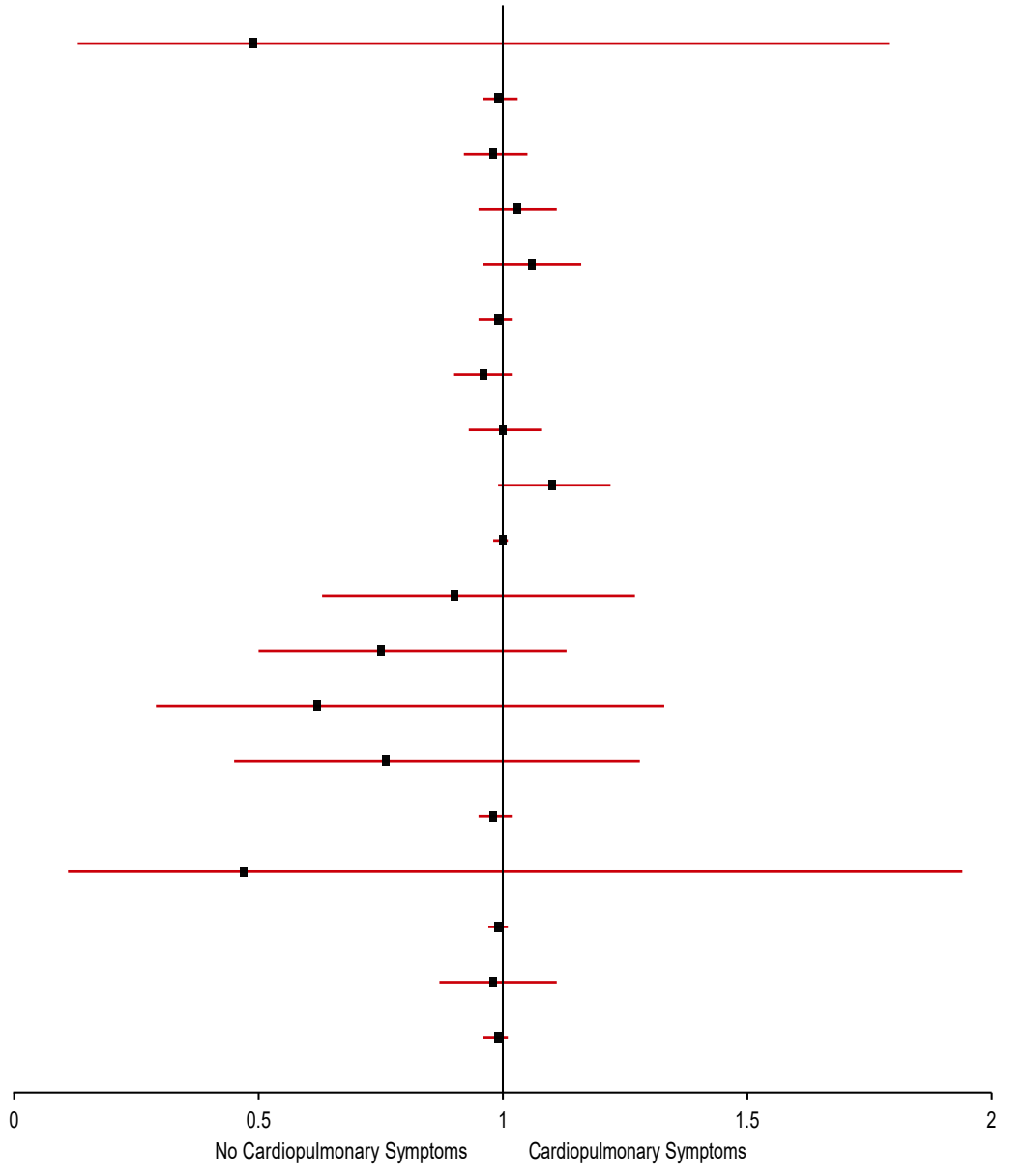

Figure 3. Prevalence and CMR/PFT/CPET determinants of cardiopulmonary symptoms (chest pain, palpitations, syncope, dyspnoea, or dizziness). A: At 2-3 months, $83 \%$ of patients experienced at least one cardiopulmonary symptom. By 6 months, this improved to 53\% and was comparable to controls. B: Forest plot depicts the odds of having any cardiopulmonary symptom at 6 months using any of the ECG, CMR, PFT, and CPET measures. An abnormal ECG was defined as rhythm abnormalities and/or the presence of bundle branch block, ST-segment elevation/depression or T wave inversion. CMR - Cardiac magnetic resonance. CPET - Cardiopulmonary exercise testing. OR - Odds ratio. CI - Confidence interval. ECG - Electrocardiogram. LVEDV $_{\mathrm{i}}$ - Left ventricular end-diastolic volume (indexed). LVESV - $^{-}$

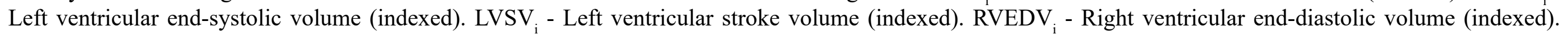
$\mathrm{RVESV}_{\mathrm{i}}$ - Right ventricular end-systolic volume (indexed). $\mathrm{RVSV}_{\mathrm{i}}$ - Right ventricular stroke volume (indexed). LGE - Late gadolinium enhancement. DL $\mathrm{CO}^{-}$Diffusing capacity for carbon monoxide. $\mathrm{pVO}_{2}$ - Peak oxygen consumption. $\mathrm{VE} / \mathrm{VCO}_{2}$ - Ventilatory equivalent for carbon dioxide. $\mathrm{O}_{2}$ pulse - Oxygen pulse. 